\title{
Mineralogical, petrological and planetological heritage. The (Italian) story so far
}

\author{
Giovanni Pratesi ${ }^{1,2}$ (D) Annarita Franza ${ }^{1}$ (D)
}

Received: 11 October 2020 / Accepted: 15 December 2020 / Published online: 28 January 2021

(c) The Author(s) 2021

\begin{abstract}
The goal of this work is to further increase the use, by all the stakeholders, of well-established and official cataloguing methods for the preservation, valorisation and study of naturalistic heritage. The work describes the standards of the Central Institute for Cataloguing and Documentation (ICCD) for cataloguing the Italian mineralogical, petrological and planetological heritage to the community of scientists, curators and museum practitioners. This work then provides an overview of the geoscientific heritage already catalogued through these standards and freely available for study and research purposes on the SIGECweb online database. Finally, the importance of a standardized cataloguing —in the comprehension of the historical, cultural and ethical aspects relative to the conservation and valorisation of the geoscientific heritage—will also be highlighted.
\end{abstract}

Keywords Geo-mineralogical heritage $\cdot$ Cataloguing $\cdot$ ICCD $\cdot$ Sigecweb $\cdot$ Geoethics

\section{Introduction}

Studies over the past two decades have shown that the debate about geoscientific heritage has evolved passing from discussions on what kind of geoscientific heritage was worthy of conservation to considering the best museum practices and policies for both its management and the valorisation of its scientific, educational and touristic meanings (Barettino et al. 2000; Burek and Prosser 2008; Hoffman 2009; Magagna et al. 2013; Garofano 2015; De Lima and De Souza Carvalho 2020). In this regard, establishing a sustainable and easy-to-follow museum cataloguing practice, based on both standardized and robust rules, will certainly help to achieve the aforementioned goals. A considerable amount of literature has been published on museum cataloguing. These studies, among them the major work of Loubar (2017), underlined how a cataloguing campaign carried out using appropriate standards and controlled vocabularies made it possible to (re)discovery museum collections, acquiring historical and scientific data that would have been difficult

Giovanni Pratesi

giovanni.pratesi@unifi.it

1 Dipartimento di Scienze della Terra, Università degli Studi di Firenze, Via Giorgio La Pira 4, 50121 Firenze, Italy

2 Istituto di Astrofisica e Planetologia Spaziali, INAF, Via Fosso del Cavaliere 100, 00133 Roma, Italy to retrieve otherwise. For instance, the National Meteorite Collection at the Smithsonian Institution preserves more than 45,000 meteorite specimens, including 10,000 polished thin sections. All these specimens have been carefully catalogued -encompassing the thin sections that have been accompanied by images realised by means of the optical and the scanning electron microscope as well as at the Fouriertransform infrared spectrometer- and the data have been made available freely on the online database Smithsonian Geogallery (https://geogallery.si.edu/gems-minerals-meteo rites-rocks). As stated by Beolchini (2002), there is an ever increasing need to store historical collections in electronic databases to manage and publish specimen information on a national and international level, since archives and scientific museums can be considered important tools for cataloguing bio- and geodiversity alongside born-digital data (Suarez and Tsutsui 2004; Hanner et al. 2009; Leo 2011; Gippoliti et al. 2014; Farley et al. 2018; Vicentini et al. 2018, 2020; Walisch et al. 2019; Kays et al. 2020).

In Italy, the Italian Code of Cultural Heritage and Landscape (Legislative Decree n. 42 of 22 January 2004 and subsequent modifications) states that cultural property also included "the collections of museums, picture galleries, art galleries and other exhibition venues of the State, the Regions, other territorial government bodies, as well as any other government body and institute" (art. 10, part 2, letter a). The status of cultural property is, therefore, attributed 
to a "collection" regardless of the various kinds of objects. Furthermore, in Annex A, paragraph 13, letter a, the categories of cultural properties include "collection and specimens belonging to zoological, botanical, mineralogical and anatomical collections". The process of recognition of naturalistic heritage as a cultural property was helped by the Central Institute for Cataloguing and Documentation (ICCD), which promoted the establishment of cataloguing standards for both the technical-scientific and naturalistic heritages through a memorandum of understanding (2005) between the Ministry for Cultural and Environmental Heritage (MiBAC), the Conference of the Rectors of Italian Universities (CRUI), the National Agency for New Technologies, Energy and Sustainable Economic Development (ENEA), and the National Association for Scientific Museums (ANMS). This activity was part of a project to enrich the cluster of cataloguing standards already developed by the ICCD for the archaeological, architectural, ethnoanthropological and historical-artistic Italian heritage. The cataloguing standards realised by the ICCD were characterised by codified methodologies for gathering, exchanging, accessing and processing data at a national level (Cammelli 2016). As highlighted by Mancinelli (2018), the establishment of common procedures was the core of the information dissemination between the diverse actors (both public and private) operating in the cultural heritage area. These data exchange then constituted the National Catalogue of Cultural Properties as stated in the Code of the Cultural and Landscape Heritage (article 17, paragraph 5) (Moro 2015, 2017).

In 2005, the ICCD realised the PST (scientific and technological heritage) cataloguing standard for the technicalscientific heritage (Castellani et al. 2006; Miniati 2008), while two years later specific cataloguing standards were established for the preservation and valorisation of naturalistic heritage. In detail, the corpus of the cataloguing standards relative to naturalistic heritage consisted of six cataloguing cards: BN-B (naturalistic heritage-botany), BN-M (naturalistic heritage-mineralogy), BN-PE (naturalistic heritage-petrology); BN-PL (naturalistic heritage-planetology), $\mathrm{BN}-\mathrm{P}$ (naturalistic heritage-palaeontology), $\mathrm{BN}-\mathrm{Z}$ (naturalistic heritage-zoology) (Agnelli et al. 2007; Armiraglio et al. 2007; Angelelli et al. 2008; Casto et al. 2007a, b, c; Paradiso et al. 2015). Generally speaking, the cataloguing standards developed by the ICCD comprise regulations that are the registration data models, terminological tools as vocabularies and thesauri, methodologies (i.e., specific procedures and policies) realized for the various categories of cultural properties to acquire data according to homogeneous criteria. The structure of the cataloguing standards for naturalistic heritage is divided into two parts: a series of sections common to all the standards (i.e., cross-paragraphs), and a series of paragraphs developed for the different categories of naturalistic heritage in which technical information relative to the single type of specimen are reported (i.e., specialised paragraphs). In the pages that follow, it will provide an overview of the regulations, the registration data models and of the specialised paragraphs relative to the cataloguing of the geoscientific heritage, in its broadest sense, and of the mineralogical, petrological and planetological heritage in a more specific way. It is noteworthy that the ICCD standards discussed here aiming to catalogue the specimens that are included in rock, mineral or meteorite collections, even if the Code of the Cultural and Landscape Heritage (art. 10) attributes the status of naturalistic heritage to the collection as a whole, and not to the individual samples in it. On the other hand, the same Code requires the cataloguing of every cultural property (art. 17). In 2012, after that the cataloguing standards of the naturalistic heritage were established, the National Association of Scientific Museums (ANMS) has promoted the CollMap project, that is an online database aiming to map the zoological and naturalistic collections preserved in the Italian natural history museums. CollMap provides data on the number of the samples encompassing the analysed collection other than generic information about its historical, taxonomic, and biogeographical value (Vomero 2013; Marangoni and Miglietta 2015; Marangoni et al. 2017). However CollMap is not able to catalogue a single specimen. On the contrary, the BN-M, BN-PE and BN-PL cataloguing standards provide a detailed description of all the specimens encompassing in a rock, mineralogical or meteorite collection in a conceptual framework of elements, relationships and cataloguing rules that give an exhaustive museological, historical and scientific description of the single sample and, consequently, of the collection. It should be noted that if cataloguing is an essential part of managing a museum's key asset (i.e., its collections), only the catalogue campaigns carried out through official and standardised criteria can help natural history museums to direct properly their collecting policies and activities such as research, interpretation, conservation, exhibition organisation, and publications. In this regard, it is important to note that the standards promoted by the ICCD are the only cataloguing policies recognised at a national level.

The work will then examine the current status of the cataloguing of the geoscientific heritage in Italy through the analysis of the records included in the SIGECweb (General Catalogue Information System) online database (http://www. sigecweb.beniculturali.it). As pointed out by Calosso et al. (2008), the SIGECweb is a web-based platform that manages the entire ICCD cataloguing system from the development of new cataloguing standards to data dissemination. The SIGECweb includes more than 2.6 million of cataloguing records relative to the Italian cultural properties. Among these, 831,114 cataloguing cards were available to both scientific institutions and researchers through the National Catalogue of Cultural Properties (http://www.catalogo.benic 
ulturali.it) (Corradini 2013; Moro 2015, 2017; Plances and Benes 2015; Cignoni and Meloni 2019). After having analysed the mineralogical, petrological, and planetological cataloguing cards on SIGECweb, this work will discuss how a standardised cataloguing of the geoscientific heritage on a national level can improve not only the practices and policies for its preservation and conservation, but also its valorisation through research projects aiming to investigate the historical, cultural, and ethical aspects related to this unique part of the Italian naturalistic heritage.

\section{Materials and methods}

Here we show the specialised paragraphs contained in the $\mathrm{BN}-\mathrm{M}, \mathrm{BN}-\mathrm{PE}$, and BN-PL cataloguing standards. While the categories of naturalistic objects referring to the first two standards are quite obvious (i.e., mineral and rock specimens), the last cataloguing standard refers to the collection of meteorites that, due to their peculiarities, cannot be catalogued using the same standards realized for rocks and minerals. It is worth noting that in this study, the term "specimen" refers indifferently to a mineral, rock, or meteorite specimen; otherwise, when referring to a specific kind of object, the terms mineral, rock or meteorite are used.

Table 1 describes the first specialised paragraph (OG) of the BN-M, BN-PE and BN-PL cataloguing standard. The structured field OGT (object) contains data useful for the typological and terminological identification of the catalogued specimen. The subfield OGTD (definition) provides a formal description of the specimen: it may be the formal and official name of the species but, if not available,

Table 1 The OG paragraph

\begin{tabular}{llllll}
\hline & & Lung & Rip & Obbl & Voc \\
\hline OG & Object & & & & \\
OGT & Object & & $*$ & \\
OGTD & Definition & 70 & & $*$ & Yes \\
OGTL & Language code & 3 & & & Yes \\
OGTV & Identification & 70 & & Yes \\
OGTO & Container type & 70 & & \\
OGTC & Collection name & 50 & & \\
QNT & Quantity & & & \\
QNTN & Number & 25 & & & \\
QNTI & Quantity set & 5 & & & \\
QNTS & Unknown quantity & 2 & & & Yes \\
\hline
\end{tabular}

This paragraph is the same for the BN-M, BN-PE, and BN-PL cataloguing standards

LUNG contains the maximum number of text characters, RIP indicates the possibility to repeat a field and OBB, when marked by an asterisk (*), its mandatory filling. VOC specifies whether the field has to be compiled using a pre-compilated vocabulary or not even an obsolete name or a simple description taken from museum catalogues and inventories could also be reported. For instance, museum catalogues often reported the term tourmaline. We know that it refers to a supergroup and not to a species, but until the specimen will be analysed, this is the term that has to be reported in OGTD. However, even when a species name is given, the old name will continue to be retained because this subfield, like many others in the cataloguing standards discussed here, is recursive. The subfield OGTV (identification) describes the catalogued specimen according to an open glossary of terms, indicating whether the specimen was part of a museum collection, of a series of specimens, or of a set of specimens not necessarily similar but collected on the same site or on the same occasion. In the eventuality that the catalogued specimen was part of a museum or private collection (Fig. 1), the latter could be described in OGTC (collection name).

The structured field QNT indicates the quantity of the objects composing the catalogued specimen. This field is

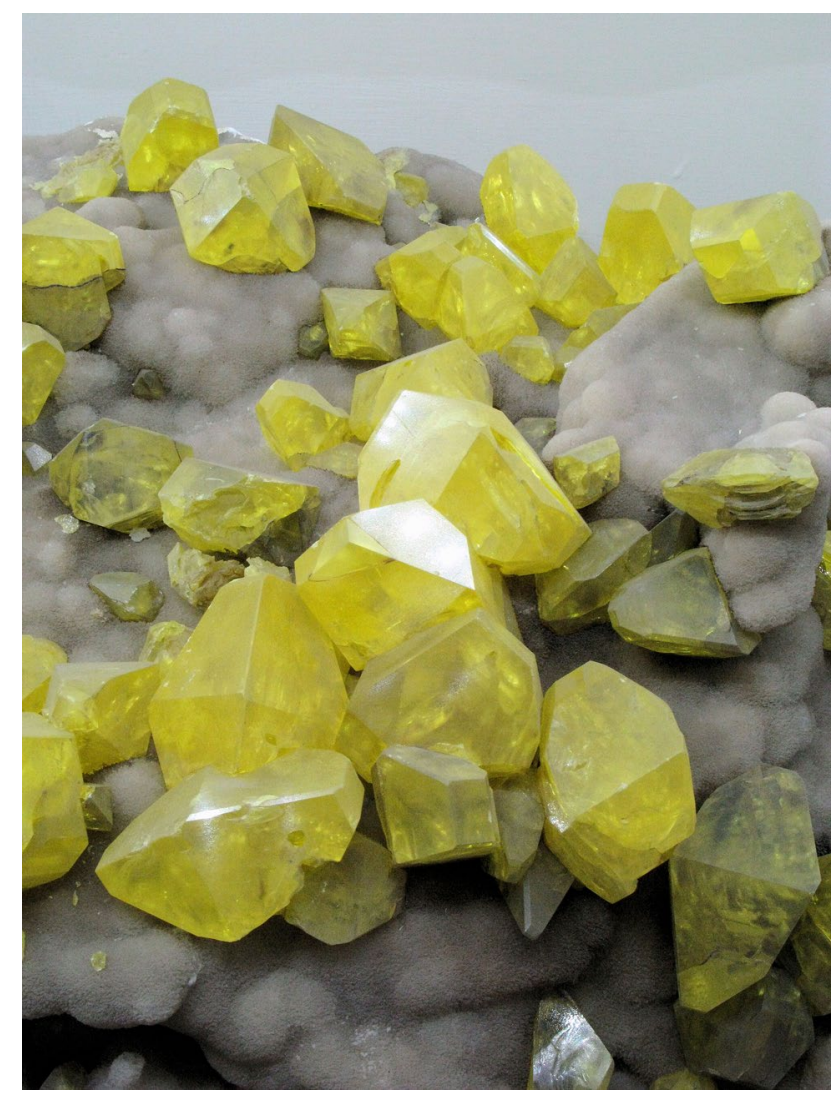

Fig. 1 This wonderful sulphur specimen $(65 \times 45 \times 25 \mathrm{~cm})$ from Sicily, now in the collections of the Natural History Museum of the University of Firenze, was previously owned by the well-known dealer and collector Alberto Ponis. Cataloguing allows you to keep track of the various collection steps that often characterize the most important samples. This is a foremost information for the history of collectors and collections 
useful to provide information about rock and meteorite collections where the specimen can be composed of several fragments or samples. Also in the cataloguing of minerals, sets containing several samples may occur. The structured field QNT could, therefore, be used in the occurrence of sets for which the historical value of the whole exceeds the scientific value of the individual specimens, or in case of groupings of relatively similar samples of the same species for which the scientific and economic value of the individual specimen does not justify individual cataloguing. In the event that the sum of the specimens could not be determined, the field QNTS could be filled with the abbreviation NR (unknown quantity).

Table 2 shows the paragraph SM concerning the systematic mineralogy, i.e. a specialised section containing several structured fields where data about the nomenclature (SMN), systematics (SMS), type specimen (SMT) and crystallographic characteristics (SMC) of the catalogued specimen can be provided. This paragraph also described the habit and eventually, if measured, the physical and optical properties of the sample. Furthermore, text labels might also be reported in the field SME (tags and labels). The terms in the vocabularies of SM have been taken from scientific publications and from terminologies recommended by the International Mineralogical Association (IMA), the Commission on New Minerals and Mineral Names (CNMMN), the Commission on Classification of Minerals (CCM), and the Commission on New Minerals, Nomenclature and Classification (CNMNC). Glossaries adopted by the Commission on Museums (CM), Commission on Gem Material (CGM), and by the Working Group on Inclusions in Minerals (WGIM) have also been taken into consideration. With regard to mineralogical species, the only official source is the dataset containing 5650 currently valid mineral species recognized by the IMA and CNMMN (Levison 1966; Sanero and Gottardi 1968; Bailey 1980, 1982; Bayliss and Levinson 1988; Makovicky 1989; Hawthorne et al. 1995; Martin 1998; De Fourestier 2002). Furthermore, the Mineralogical Society of America and the European Mineralogical Union provided a list of reliable mineralogical database (i.e., Athena Mineralogy, Mindat, Mineralogy Database, Euromin Project). Concerning the use of Dana's and Strunz's mineralogical classification, useful information could be found in Gaines et al. (1997) and Strunz and Nickel (2001). For a glossary of terms in Italian, an interesting source was Carusone and Olivetta (2006). In SMNP is then possible to indicate polytypes, while in SMNV the mineral variety and in SMNS any synonym reported on the museum label or in other archival documentation relative to the catalogued specimen (De Fourestier 1999; Bayliss 2000; Ferraris et al. 2001). SMS provide data about the systematics of the mineralogical species. In particular, this field make it possible to insert data about the chemical-structural mineral classification along with information about the mineralogical composition (e.g., SMSF and SMSE report the experimental and theorical formulas). SMTT (type) defines the type mineral specimen and it could be filled through a pre-compiled list of terms (i.e., holotype, cotype and neotype) approved by CM, CNMMN and IMA (Dunn and Mandarino 1987). The name(s) of the author(s) that described for the first time the mineral species of the catalogued specimen could be reported in SMTA and the relative bibliographical reference in SMTB. SMC contains the crystallographic features of the catalogued mineral. Some of these data (i.e., SMCS, SMCL, SMCG, SMCP, and SMCZ) are common to all the specimens belonging to the same mineralogical species, while other data (i.e. SMCA, SMCB, SMCC, SMCF, SMCE, SMCM, SMCV) could show slight but significant variations typical of the single mineral sample. SMAB (appearance) describes the relationships between crystal and matrix. This field is also useful to catalogue cut-stones, while habit and possible cutting-styles could be reported in SMAA. The Miller Indices could be specified in SMAF. The possible presence of twinning, pseudomorphism, paramorphism, zoning, and inclusion in the catalogued specimen could be listed, respectively, in SMAG, SMAP, SMAS, SMAZ, and SMAI. In the structured field SMF data about the physical properties of the catalogued specimen are provided. For instance, in SMFC quantitative data about the colour of the mineral are given according to a standardised scale (e.g. RGB, HSB, CIE, Munsell etc.), while in the subsections SMFT, SMFB and SMFP are provided information about the mineral streak, luster and transparency. SMFD expressed the density $\left(\mathrm{g} / \mathrm{cm}^{3}\right)$ measured on the catalogued mineral. In SMFG could be indicated the Gladstone-Dale Index that allowed one to derive a compatibility index of the physical and chemical data used to characterize a mineral (Mandarino 2007). In his review of the Gladstone-Dale relationship in minerals, Mandarino (1981) elaborated the Compatibility Index (CI) in comparing the physical and optical properties of minerals. CI could be specified in SMFI and its value is a required calculation by IMA for the approval of a new mineral species. SMFH contains information based on the Mohs scale of mineral hardness that is a qualitative ordinal scale characterising the scratch resistance of different minerals through the ability of a harder material to scratch a softer material (Broz et al. 2006). Vickers hardness or microindentation hardness testing, which is a method for measuring the hardness of a mineral on a microscopic scale (Hermann 2011), could be reported in SMFN. SMFA describes the level of cleavage of the catalogued mineral according to a predefined terminology, i.e. absent (no cleavage), poor (difficult-formed cleavage surfaces), distinct (recognisable cleavage surfaces), good (good cleavage surfaces), excellent (excellent cleavage surfaces), perfect (perfect and glossy cleavage surfaces). The type of fracture-surfaces could be reported in SMFU as 


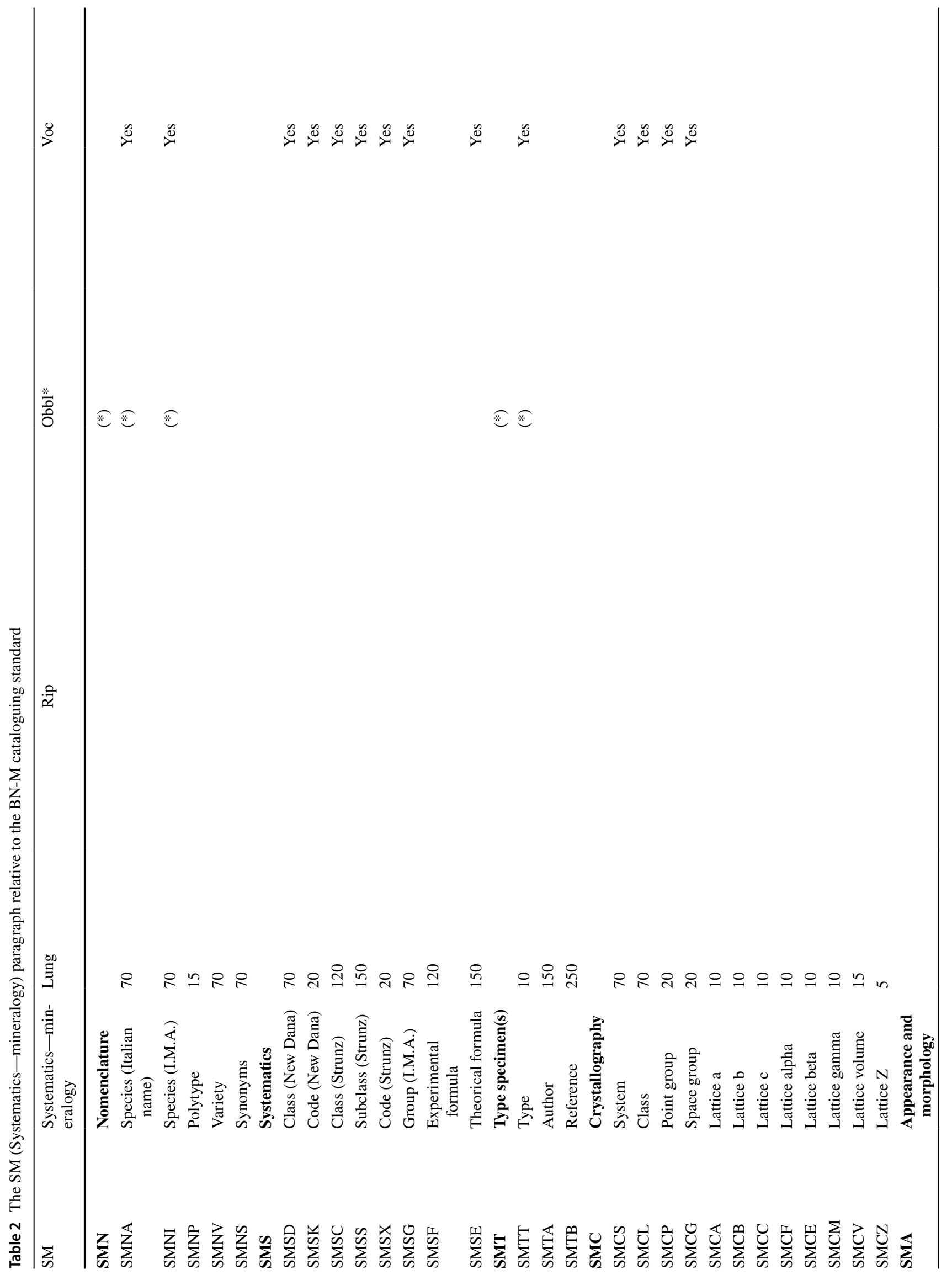




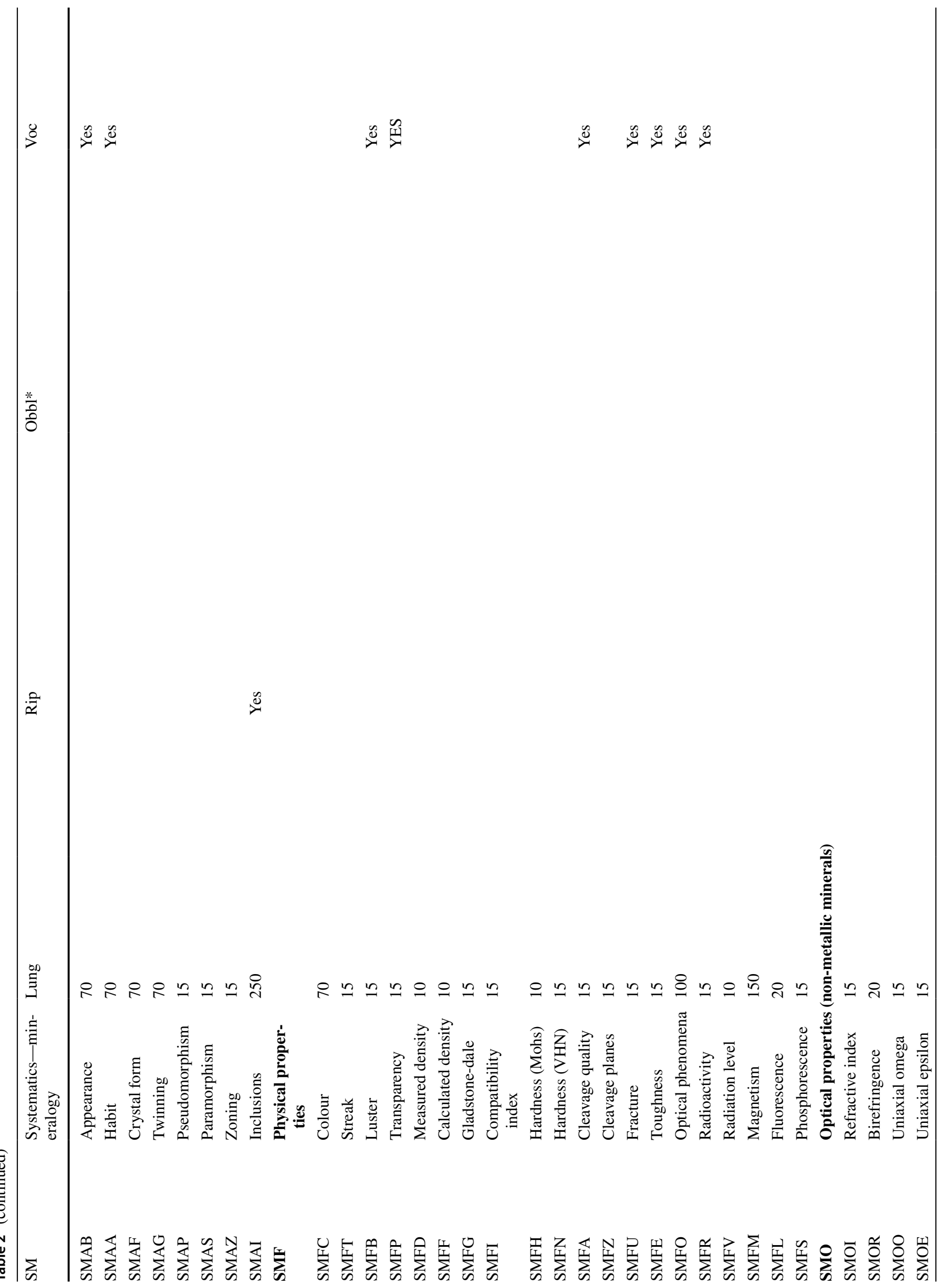




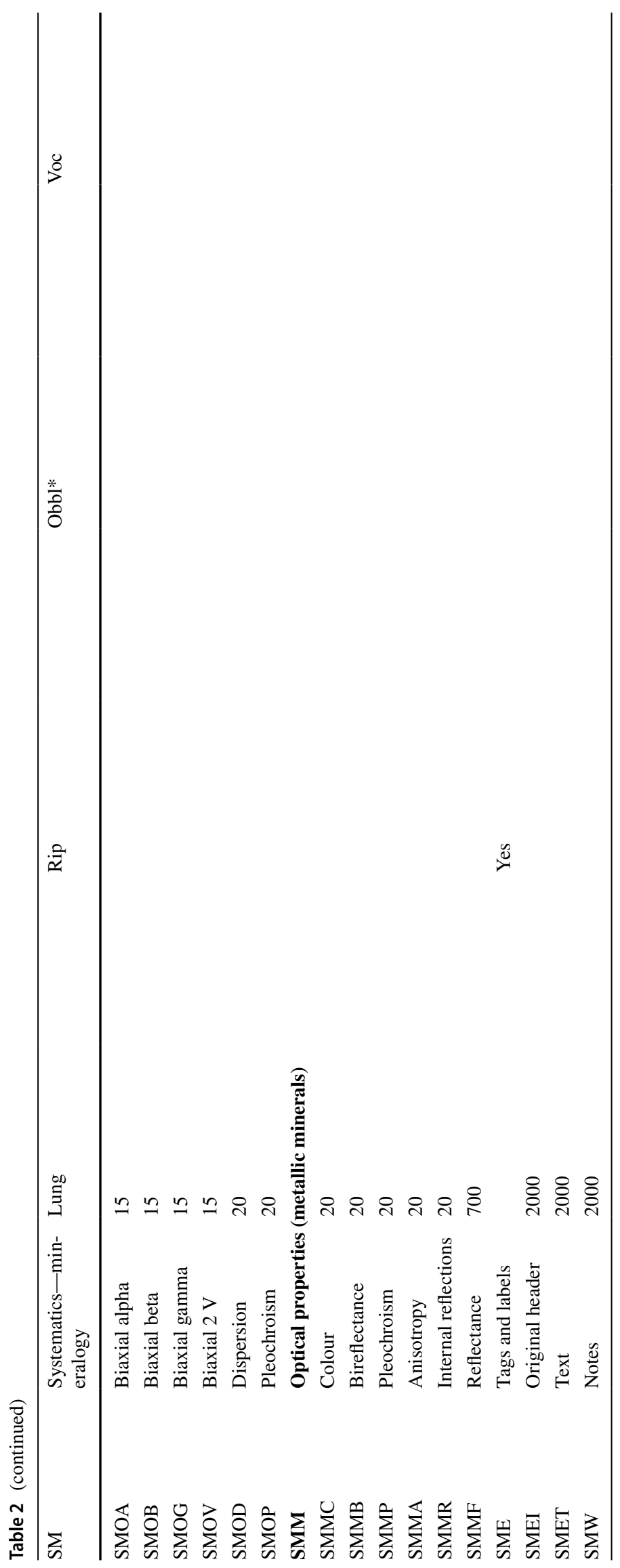


conchoidal (curved fracture surfaces), even (smooth fractures), or uneven (curved fracture surfaces). SMFE is related to the toughness of the catalogued specimen which could be elastic (it might be bend and snap back to its original shape after the stress is released), ductile (it might be drawn into wire), malleable (it might be flattened or deformed by hammering without breaking), sectile (it might be cut into thin shavings by a knife or other sharp object). SMFO concerns the optical phenomena of the catalogued specimen. The terms proposed for completing these subsections are asterism (a type of chatoyancy in which the inclusions reflecting the light are arranged in a pattern radiating outwards from a point producing star-like patters), chatoyancy (optical phenomenon caused by the light off closely packed parallel inclusions in cavities), iridescence (the production of a rainbow of colours caused by intereference of light in thin films of different refractive indices and varying thickness), labradorescence (also known as schiller, it is a particular type of iridescence found in labradorite and a very few other minerals), opalescence (it refers to an opal-like play of light-producing flashes of colours that may appear like a patch-work of different colours that are not really there). The presence of radioactivity - a property that, even if not too prevalent in minerals, might be useful in their identification - can be indicated in SMFR using the terms present, not determined or not detected. Whether present, its value can then be reported in SMFV. Magnetism is another property that is found in some minerals and whose presence could be specified in SMFM as follows: type of magnetism, Curie temperature $\left(\mathrm{T}_{\mathrm{C}}\right)$, transition temperatures $\left(\mathrm{T}_{\mathrm{I}}\right)$, saturation magnetization, magnetic field (Hsat), magnetic coercivity (Hc), remanence or residual magnetism (Hcr). SMFL and SMFS report the fluorescence and the phosphorescence of the catalogued mineralogical specimen. SMO and its subsections describe the optical properties in non-metallic minerals. Data should only be entered if obtained from the catalogued specimen. For an explanation of the terms reported in these sections and an introduction to the methodologies used in crystallographic optics see Mazzi and Bernardini (1992), Nesse (2004). Whereas if the catalogued sample is a metallic mineral, data regarding its optical properties should be given in SMM and subsequent subsections (Ixer 1990; Criddle and Stanley 1993; Nesse 2004). Any information about museum labels should be reported in SME (tags and labels) and its subsections SMEI (original header), SMET (text), and SMW (notes).

Turning now to the cataloguing of rocks, that requires the standard BN-PE (petrological heritage), it is possible to see in Table 3 the structured fields and the relative subfields useful to the systematic classification and description of the rock specimens. The glossaries proposed for completing these sections were taken from recommendations of the Commission on Systematics in Petrology (CSP), and by the
International Union of Geological Sciences (IUGS) (Fettes and Desmons 2011). With regard to igneous and sedimentary rocks, some cataloguing sections -and relative glossaries-were taken from the Igneous Data Base (IGBA) and from the Sedimentary Data Base. Both of them were realized by the Sub-commission on Data Bases in Petrology (SDBP) (La Maitre et al. 2002). In the structured field SRN, data about lithology and rock type determination can be given (Fig. 2). In this regard, SRNT allows to classify the type of rock as follows: igneous rock, plutonic igneous rock, volcanic or subvolcanic rock, sedimentary rock, metamorphic rock, metamorphic rock-schist, gneiss or granofels type. The rock name of the catalogued sample should be reported in Italian in SRNP (Carusone and Olivetta 2006) whereas the rock name of the specimen should be indicated in English-according to the IUGS nomenclature-in SRNR. Rock variety and commercial name can then be specified in SRNV and SRNC.

The structured field SRC describes the petrographic features of the catalogued specimen in a broad sense, extended also to sedimentological and textural features. SRC is organized in the following subfields: SRCE-eruptive type or mode of occurrence, SRCD-diagenetic grade, SRCM-metamorphic grade, SRCP/SRCS/SRCB-primary, secondary and biogenic structures, SRCR-type of texture, SRCG-grain contact, SRCF-grain shape, SRCX-matrix, SRCC-cement, SRCZ-alteration, and SRCH-type of alteration. Modal mineralogy can be given in SRM, including data about primary (SRMP) and accessory minerals (SRMA) along with their mineral information flags (SRMT). Normative mineralogy should be specified according to the CIPW norm in SRMN (Pruseth 2009). Geotechnical properties as density (SRGD), porosity (SRGP) (i.e., primary-SRGA, secondary-SRGB, and effective-SRCG), permeability (SRGE), and resistivity (SRGR) can be indicated in SRG paragraph and its subfields. SRF describes the physical characteristics of the catalogued specimen, providing data about the colour index (SRFI), the colour of the sample according to Munsell colour chart (SRFC), and its palaeomagnetism (SRFP). The possible presence of radioactivity should be reported in SRFR and its value -expressed in $\mathrm{mR} / \mathrm{hr}$ or $\mu \mathrm{Sv} / \mathrm{hr}-$ listed in SRFV. Paleontological data pertaining to the catalogued specimen as relative age (SRLE) and biozone (SRLB) can also be reported in SRL paragraph. In this regard, the various types of biozones (i.e., distribution biozone, interval biozone, lineage biozone, association biozone, abundance biozone) are taken from the Guida Italiana alla Classificazione e alla Terminologia Stratigrafica (2003). The absolute age of the catalogued specimen should be indicated in SRRE, specifying in SRMM the methodology used to acquire the data (e.g., Carbon-14, isochrone, magnetic striping etc.) as reported in the IUGS' Age Method Code Database. The lithological representativity of the catalogued specimen depending on 
Table 3 The SR (Systematicspetrology) paragraph relative to the BN-PE cataloguing standard

\begin{tabular}{|c|c|c|c|c|c|}
\hline$\overline{\mathrm{SR}}$ & Systematics-petrology & Lung & Rip & Obbl & $\overline{\text { Voc }}$ \\
\hline SRN & Classification & & & $(*)$ & \\
\hline SRNT & Type of rock & 100 & & $(*)$ & yes \\
\hline SRNP & Rock name (Italian name) & 100 & & $(*)$ & yes \\
\hline SRNR & Rock name (IUGS) & 100 & & & Yes \\
\hline SRNV & Variety & 100 & & & \\
\hline SRNC & Trade name & 200 & & & \\
\hline SRNN & Other names & 200 & & & \\
\hline SRC & Petrographic characteristics & & & & \\
\hline SRCE & Eruptive type or mode of occurrence & 50 & & & Yes \\
\hline SRCD & Diagenetic grade & 100 & & & Yes \\
\hline SRCM & Metamorphic grade & 100 & & & Yes \\
\hline SRCP & Primary structures & 100 & & & Yes \\
\hline SRCS & Secondary structures & 100 & & & Yes \\
\hline SRCB & Biogenic structures & 100 & & & Yes \\
\hline SRCA & Other structures & 100 & & & \\
\hline SRCR & Type of texture & 50 & & & Yes \\
\hline SRCG & Grain contact & 50 & & & \\
\hline SRCF & Grain shape & 50 & & & \\
\hline SRCT & Roundness & 50 & & & \\
\hline SRCX & Matrix & 100 & & & \\
\hline SRCC & Cement & 50 & & & \\
\hline SRCZ & Alteration & 50 & & & Yes \\
\hline $\mathrm{SRCH}$ & Type of alteration & 100 & & & Yes \\
\hline SRM & Mineralogy & & Yes & & \\
\hline SRMP & Main minerals & 300 & Yes & & Yes \\
\hline SRMA & Accessory minerals & 300 & Yes & & Yes \\
\hline SRMT & Attributes & 200 & & & Yes \\
\hline SRMN & Normative mineralogy & 300 & & & Yes \\
\hline SRG & Geotechnical properties & & & & \\
\hline SRGD & Density & 10 & & & \\
\hline SRGS & Cohesion & 15 & & & Yes \\
\hline SRGP & Porosity & 3 & & & \\
\hline SRGA & Primary porosity & 15 & & & Yes \\
\hline SRGB & Secondary porosity & 15 & & & Yes \\
\hline SRGC & Effective porosity & 3 & & & \\
\hline SRGE & Permeability & 10 & & & \\
\hline SRGR & Resistivity & 10 & & & \\
\hline SRF & Physical characteristics & & & & \\
\hline SRFI & Colour index & 30 & & & \\
\hline SRFC & Colour & 100 & & & \\
\hline SRFP & Paleomagnetism & 100 & & & \\
\hline SRFR & Radioactivity & 15 & & & Yes \\
\hline SRFV & Radioactivity level & 10 & & & \\
\hline SRFA & Other & 200 & & & \\
\hline SRL & Palaeontological information & & & & \\
\hline SRLP & Palaeontological content & 300 & & & \\
\hline SRLE & Relative age & 50 & & & \\
\hline SRLB & Biozone & 100 & & & Yes \\
\hline SRR & Radiometric dating & & Yes & & \\
\hline SRRM & Method & 50 & & & Yes \\
\hline SRRE & Absolute age & 10 & & & \\
\hline
\end{tabular}


Table 3 (continued)

\begin{tabular}{|c|c|c|c|c|c|}
\hline SR & Systematics-petrology & Lung & Rip & Obbl & Voc \\
\hline SRI & Other information & & & & \\
\hline SRIR & Overall lithological representativeness & 10 & & & Yes \\
\hline SRIP & Sample availability & 4 & & & \\
\hline SRIS & Thin section availability & 4 & & & \\
\hline SRIG & Granulates availability & 4 & & & \\
\hline SRIM & Use as stone material & 12 & & & Yes \\
\hline SRIT & Field of application (link to other ICCD cards) & 100 & & & \\
\hline SRIU & Reference to other databases & 150 & & & \\
\hline SRT & Type specimen(s) & & & $(*)$ & \\
\hline SRTT & Type & 10 & & $(*)$ & Yes \\
\hline SRTA & Author & 150 & & & \\
\hline SRTB & References & 250 & & & \\
\hline SRE & Tags and labels & & Yes & & \\
\hline SREI & Original header & 2000 & & & \\
\hline SRET & Text & 2000 & & & \\
\hline SRA & Notes & 2000 & & & \\
\hline
\end{tabular}

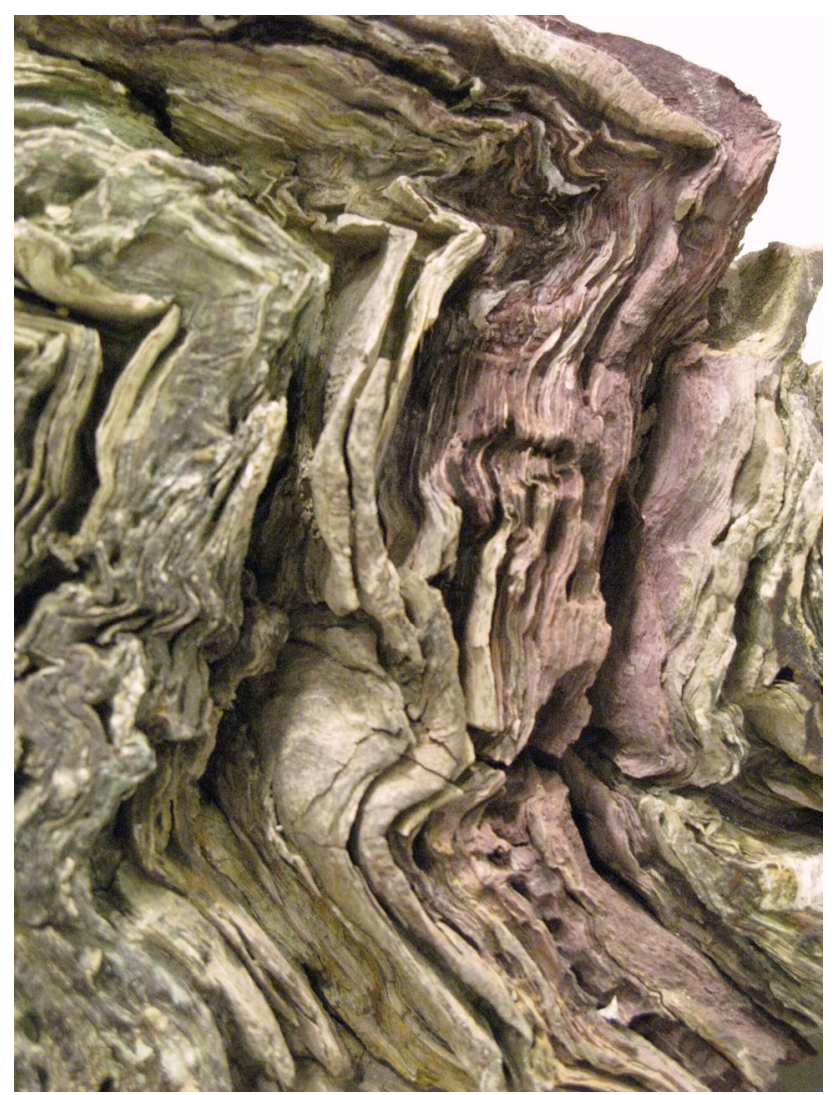

Fig. 2 Varicoloured slates of the Gràssera Unit. Cavo, Elba Island, Tuscany, Italy (from the collections of the Natural History Museum of the University of Firenze). Rock collections are not only a key for interpreting and teaching geology but also a crucial tool for scientific research. Cataloguing is the best way to make all the information on the sample always stored and accessible previously acquired data, sampling and on the geological context - should be indicated in SRIR using a predefined terminology (i.e., good, discrete, sufficient, insufficient, indeterminate). Information about the availability of the samples, thin sections, and granulates should be given, respectively, in SRIP, SRIS, and SRIG. If the catalogued specimen could be used as a stone material (e.g., cutting stone), this information should be provided in SRIM and in SRIT the fields of application. In particular, the SRIT field can be used also when a possible link to other ICCD cards may occur (Re et al. 2013, 2015). In case that other databases (e.g., IUGS, IGBA; SEDBA, national geologic databases and catalogues of natural history museums) should contain additional data describing the same type of rock as the catalogued sample, this information could be specified in SRIU. Noteworthy, the BN-PE standard can also be used for cataloguing tektites and impact rocks (Giuli et al. 2008) that in the last decades have been extensively studied by many authors (e.g. Giuli et al. 2000).

So far, this paper has focused on the cataloguing of mineralogical and petrological heritage. The following paragraph instead will discuss the cataloguing of meteorite specimens (Table 4). The BN-PL (naturalistic heritageplanetology) standard was, in fact, developed to specifically catalogue the meteorite specimens preserved in the Italian natural history museums (Fig. 3). Our description of this standard begins with paragraph SP (systematicsmeteorites) suitable to gather all the systematic data. Glossaries and thesauri useful to structured fields and related subfields compilation were taken from the guidelines of the Meteoritical Society. This is an international organisation, established in 1933 and dedicated to the studies of meteorites and other extra-terrestrial materials (Marvin 
Table 4 The SP (Systematics-meteorites) paragraph relative to the BN-PL cataloguing standard

\begin{tabular}{|c|c|c|c|c|c|}
\hline SP & Systematics-meteorites & Lung & Rip & Obbl & Voc \\
\hline SPN & Nomenclature & & & $(*)$ & \\
\hline SPNN & Name & 100 & & $(*)$ & \\
\hline SPNE & Type & 20 & & & Yes \\
\hline SPNC & Class & 50 & & & Yes \\
\hline SPNG & Group & 50 & & & Yes \\
\hline SPNT & Petrologic type & 5 & & & Yes \\
\hline SPNL & Fall/find & 4 & & & Yes \\
\hline SPND & Date & 10 & & & \\
\hline SPNS & Owner of the type specimen & 100 & & & \\
\hline SPNP & Weight of the type specimen & 10 & & & \\
\hline SPNM & Owner of the main mass & 100 & & & \\
\hline SPNK & Weight of the main mass & 10 & & & \\
\hline SPNW & Total known weight & 10 & & & \\
\hline SPC & Petrographical characteristi & & & & \\
\hline SPCS & Shock stage & 2 & & & Yes \\
\hline SPCT & Texture & 50 & & & Yes \\
\hline SPCA & Weathering grade & 2 & & & Yes \\
\hline SPCR & Chondrules/matrix ratio & 10 & & & \\
\hline SPCC & Chondrule types & 150 & & & Yes \\
\hline SPM & Mineralogical characteristic & & & & \\
\hline SPMF & Fayalite (mole\%) & 15 & & & \\
\hline SPMR & Ferrosilite (mole \%) & 15 & & & \\
\hline SPMA & Anorthite (mole\%) & 15 & & & \\
\hline SPMO & Olivine (vol\%) & 10 & & & \\
\hline SPMP & Pyroxene (vol\%) & 10 & & & \\
\hline SPML & Plagioclase (vol\%) & 10 & & & \\
\hline SPMM & Metal (vol\%) & 10 & & & \\
\hline SPMS & Sulphides (vol\%) & 10 & & & \\
\hline SPMZ & Other minerals & 50 & & & \\
\hline SPO & Oxygen isotopes & & & & \\
\hline SPOA & Delta $17 \mathrm{O}$ & 20 & & & \\
\hline SPOB & Delta $18 \mathrm{O}$ & 20 & & & \\
\hline SPOC & Delta $17 \mathrm{O}$ & 20 & & & \\
\hline SPD & Dating & & & & \\
\hline SPDE & Igneous age & 15 & & & \\
\hline SPDR & $87 \mathrm{Rb} / 86 \mathrm{Sr}$ & 20 & & & \\
\hline SPDS & $147 \mathrm{Sm} / 144 \mathrm{Nd}$ & 20 & & & \\
\hline SPDU & $238 \mathrm{U} / 206 \mathrm{~Pb}$ & 20 & & & \\
\hline SPDG & Shock Age & 10 & & & \\
\hline SPDD & $87 \mathrm{Rb} / 86 \mathrm{Sr}$ & 20 & & & \\
\hline SPDP & $40 \mathrm{Ar} / 40 \mathrm{~K}$ & 20 & & & \\
\hline SPDX & Cosmic ray exposure age & 10 & & & \\
\hline SPDH & $3 \mathrm{He}$ & 10 & & & \\
\hline SPDN & $21 \mathrm{Ne}$ & 10 & & & \\
\hline SPDA & $38 \mathrm{Ar}$ & 10 & & & \\
\hline SPDT & Terrestrial age & 10 & & & \\
\hline SPDC & $14 \mathrm{C}$ & 10 & & & \\
\hline SPDB & $10 \mathrm{Be}$ & 10 & & & \\
\hline SPDL & $36 \mathrm{Cl}$ & 10 & & & \\
\hline
\end{tabular}

Table 4 (continued)

\begin{tabular}{llllll}
\hline SP & Systematics-meteorites & Lung & Rip & Obbl & Voc \\
\hline SPI & Other information & & & & \\
SPIP & Sample availability & 4 & & & \\
SPIS & Thin section availability & 4 & & & \\
SPIG & Granulates availability & 4 & & & \\
SPT & Type specimen(s) & & $(*)$ & \\
SPTT & Type & 10 & $(*)$ & Yes \\
SPTA & Author & 150 & & & \\
SPTB & References & 250 & & & \\
SPE & Tags and labels & & Yes & & \\
SPEI & Original header & 2000 & & & \\
SPET & Text & 2000 & & & \\
SPA & Notes & 2000 & & & \\
\hline
\end{tabular}

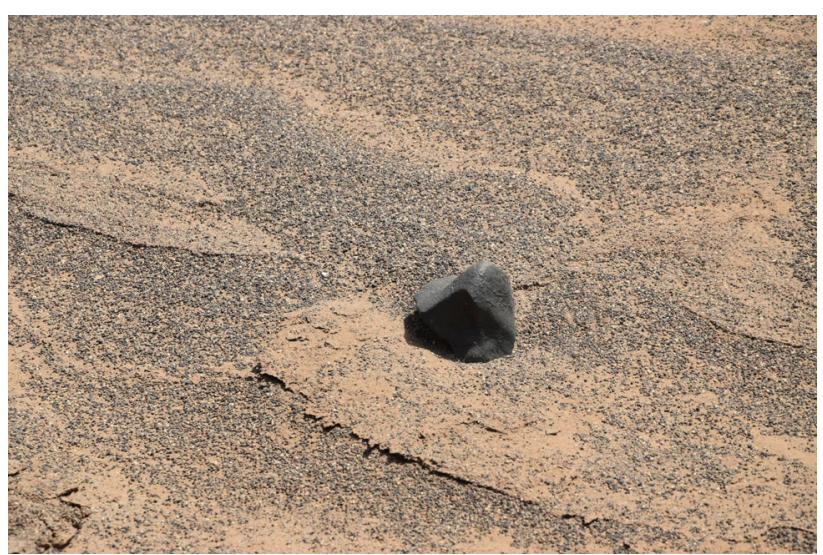

Fig. 3 The finding of a meteorite specimen during a scientific expedition in the Lut Desert (Iran). The collection enrichment, explicitly required by the Code of Cultural Heritage and Landscape, is a key goal of the scientific expeditions. In this case, there are even more data to be preserved because it is important to provide information on the so-called cultural context (the motivations and the way the expedition has been undertaken) as well as the environmental characteristics in which the specimens were collected. The meteorite of the figure is now in the collections of the Natural History Museum of the University of Firenze

1993). The Meteoritical Society also approves, through its Nomenclature Committee, all new meteorite names and classifications and record them in the Meteoritical Bulletin Database (MBD- https://www.lpi.usra.edu/meteo r/). On 8 October 2020, MBD stated 64,066 valid meteorite names, 7514 provisional names and 11,618 full-text writeups. Other sources useful for both the study and the cataloguing of meteorite specimens were the Catalogue of Meteorites (Grady 2002), the Atlas of Meteorites (Grady et al. 2014), MetBase, Antarctic Meteorite Newsletter, Meteorite Newsletter, Earth Impact Database, Lunar and Planetary Institute, JSC Astromaterials Research and 
Exploration Science, JSC Astromaterials Curation. In paragraph SPN (nomenclature), data about the classification of the catalogued meteorite specimen are provided. SPNN specifies the official name of the catalogued meteorite specimen as reported in MBD. Usually, meteorites are given names based on the place of recovery but sometimes, particularly when they are found in dense collection areas, a number can also follow the locality. In this regard, it should be noted that all the fragments belonging to a meteorite should have the same name (in field researches the belonging of specimens to the same meteorite can be occasionally found, following analysis, and then the specimens-albeit with different names - are said to be paired). SPNE specifies the meteorite type (i.e., chondrite, achondrite, stony-iron and iron), while meteorite class, group, and petrologic type are indicated, respectively, in SPNC, SPNG and SPNT. It is worth mentioning that meteorites are classified as 'falls' if they can be associated with an observed fall event and collect shortly afterwards or 'finds' if their finding on the ground is unrelated to any sighting. This is an important distinction -because finds, depending on the time they spent on Earth, are more prone to chemical interaction with the terrestrial environment (Weisberg et al. 2006) - that has to be specified in SPNL (fall/find). The date of the witnessed fall or the date of the meteorite discovery (find) should then be stated in SPND. It has to be said that the date reported in SPND could not be the same indicated in RAC (information about the recovery) within LR paragraph (recovery data). In fact, the year of the fall might be different from the year of the meteorite recovery as shown by the Sikhote-Alin meteorite, which fell in Russia on 12 February 1947, and whose fragments are still being recovered today (Komatsu et al. 2019). Data about the research institution that acted as official repository should be provided in SPNS whereas in SPNP the weight of the type-specimen can be specified. Whilst information about the public or private actor that owns the main mass of the catalogued meteorite specimen should be given in SPNM and the weight of the main mass reported in SPNK. The total known weight of the meteorite, derived from the sum of the weight of all meteorite samples belonged to the same meteorite body, can then be specified in SPNW. SPC describes the petrographic characteristics of the catalogued meteorite fragment. For instance, SPCS gives information about the degree of shock pressureranging from $\mathrm{S} 1$ (unshocked, pressure $<5 \mathrm{GPa}$ ) to $\mathrm{S} 6$ (very strongly shocked, pressures up to $90 \mathrm{GPa}$ ) - the meteorite experienced. The shock stage is assigned based on the petrographic features showed by minerals such as olivine, pyroxene, and plagioclase (Stoffler et al. 1991; Schmitt et al. 1994; Schmitt and Stoffler 1995; Kimura et al. 2003; Rubin 2004; Weisberg et al. 2006; Grady et al. 2014). Textural and micro-textural features of the catalogued sample can be listed in SPCT, and SPCA indicates the weathering grade-i.e., the alteration of the original component phases of the meteorite to phases that were more stable at Earth's surface. These parameters are usually obtained by analysing the catalogued specimen or its thin sections. A scale of weathering effects has been proposed by Jull et al. (1991) and updated by Wlotzka (1993), Wlotzka et al. (1995), Al-Kathiri et al. (2005). This classification considers six grades of weathering, beginning with minor to complete oxidation of the metal and then troilite (categories W1-W4) and continuing with at first minor (W5) and then massive (W6) alteration of mafic silicates. The chondrule-matrix relationships (SPCR) and, mainly, the chondrule type (SPCC) have the potential to distinguish between categories of chondrule forming mechanisms, revealing the processes at work in the early solar system (Hewins 1997; Connolly 2016; Hezel et al. 2018; Russell 2018). The structured field SPM accounts for the mineralogical features of the catalogued meteorite specimen, providing the average composition of main silicates along with data about specimen's modal mineralogy (Rubin 1997; Bland et al. 2004; Yaroshevsky and Ivanov 2010). The first data should be indicated in SPMF (fayalite mol\%), SPMR (ferrosilite mol\%), and SPMA (anorthite mol\%) while SPMO (olivine vol\%), SPMP (pyroxene vol\%), SPML (plagioclase vol\%), SPMM (metal vol\%), and SPMS (sulphides vol\%) reported the modal mineralogical data. In SPMZ should be specified the presence of the other minerals found in the catalogued specimens and their modal percentages in vol\%. In SPO data relative to the oxygen isotopic composition should be reported. It was worth mentioning that this parameter played a pivotal role in meteorite classification as pointed out by Clayton et al. in their seminal article (1976). Another important factor that gives useful information for the study of infall rates, meteorite distributions, weathering grade, and meteorite concentration mechanisms is the terrestrial age, i.e. the residence time of a meteorite on the surface of Earth. As said earlier, most meteorites are recovered as finds and the analysis of their terrestrial ages provides data about the effect of local geology and climate on their weathering. The terrestrial age -which is obtained by measuring the amount of radioactive isotopes that had formed in space as a result of cosmic ray bombardment (the greater the amount of unstable cosmogenic isotopes found in the meteorite, the shorter the time it will have been on Earth according to Jull et al. 1990; Wlotzka et al. 1995; Bland et al. 1996, 1998; Grady et al. 2014)-should be indicated in SPDT. SPI contains data on chips, thin sections or granulates of the catalogued specimen available for the loan (respectively, the subfields SPIP, SPIS, SPIG) and information about type specimen (SPTT), the author and the year of the species validation (SPTA) and relative 
references (SPTB). Finally, SPE provides information about museum labels (SPEI-original header and SPETtext) and other data useful to a complete cataloguing of the meteorite specimen (SPA).

Another interesting paragraph (UB), common to minerals, rocks and meteorites, is the one related to heritage data and collections. This contains the structured field STI (estimate) which provides an economic value for the asset in question. The issue of the economic value of scientific and naturalistic finds has always provoked a strong debate in the scientific community. However, it should be remembered that all the public bodies, with the transition from the financial report to the economic-patrimonial report, have a duty to estimate the economic value of their assets (Manetti and Valeri 2012). Moreover, it is useful to highlight that minerals and meteorites have a large market with well-established commercial value. The determination of the valuation requires various parameters to be taken into account-such as the state of conservation, rarity, the cultural context of origin, etc.-discussed in Pratesi et al. (2014). Since the asset may undergo revaluation or depreciation over time, all estimates can be reported, from the most recent to the oldest, preceded by the indication of the currency. It should be noted that following a substantial inventory evaluation and revaluation campaign - carried out on over 10 million specimens of its Natural History Museum-the University of Firenze has seen the value of its assets increase from 37 to over 400 million euros.

Finally, information about analyses and restoration can be found in paragraph RS (restoration and analyses). Instrumental analyses, even when very specialistic techniques are used (Borgheresi et al. 2007), are provided in ALBT (type of analysis), ALBD (date), ALBE (laboratory), ALBO (principal investigator), ALBR (data analyses), ALBN (notes).

\section{Results}

As explained in the introduction, the National Catalogue of Cultural Properties is the official national database that collected information on Italian cultural heritage (http:// www.catalogo.beniculturali.it). These data are the result of cataloguing activities carried out by diverse research institutions in Italy. The National Catalogue of Cultural Properties offers free access to researchers and users to a part of the catalogued records contained in the SIGECWeb database as monuments, historical-artistic collections, archaeological sites, scientific and naturalistic heritages. Of the 831,114 catalogued objects included in the National Catalogue of Cultural Properties, 46,689 records describe naturalistic collections catalogued using the ICCD standards for naturalistic heritage. These records are distributed in the Italian regions of Piedmont (700), Umbria (40), Sardinia (3722), Tuscany
$(39,899)$, Campania (60), Lazio (360), and Emilia Romagna (1908). The records can be classified as follows: 5816 paleontological heritages, 700 zoological heritages, 487 botanic heritages. To these have to be added, 39,626 mineralogical specimens (all of them located in Tuscany) catalogued using the BN-M standard. The cataloguing campaign was performed in 2013 by the Natural History Museum of the University of Firenze, the most important naturalistic museum in Italy and one of the largest in the world (Pratesi 2012a). The National Catalogue of Cultural Properties shows that 60 rock specimens were catalogued through the BN-PE standard and all these records are preserved in Campania. The cataloguing campaign was carried out in 2014 by the Michelangelo Museum in Caserta (Di Lorenzo 2011; Volpe 2016). At the current status of research, no cataloguing data concerning the Italian planetological heritage had been included in the National Catalogue of Cultural Properties using the BN-PL standard.

\section{Discussion}

The standards realised by the ICCD to catalogue geoscientific heritage aimed to define a methodology, presented in the previous section, to facilitate the conservation, valorisation and management of mineralogical, petrological and planetological heritage in the most objective way. The BN-M, BN-PE, and BN-PL standards established not only a clear definition of the heritage studied but also an exhaustive and rigorous cataloguing method based on predetermined criteria (e.g. systematics, classification, physical properties, museological and historical data). These cataloguing standards thus faced the geoscientific heritage from an integrated perspective, considering all its multiple dimensions (i.e. naturalistic, geological, historical and cultural). Furthermore, the systematic cataloguing through predeterminate and rigorous criteria lead to the recognizing of mineralogical, petrography, and planetological objects as scientific heritage. In this regard, Lourenço and Wilson (2013) advocated the view that, while naturalistic heritage is a concept of immediate understanding, the notion of scientific heritage is "diverse, complex, multi-layered, and more difficult to define". The same authors then underlined how the concept of scientific heritage lies "at the intersection of two distinct and complex worlds-the world of science and the world of (cultural) heritage." In this context, the term 'heritage' refers not only to buildings and landscapes of historical value but also - and among many others - to minerals, rock samples, meteorite specimens, as well as to ethical issues in conducting research and teaching practices through geoscientific materials-materials that were often dispersed in scientific museums or institutions and university collections (Cipriani and Poggi 1994; Cipriani 2007, 2011; Jardine 2013; Ludwig 
and Weber 2013; Barale et al. 2014; Marengo et al. 2014; Reis et al. 2014; Petti et al. 2015; Wolfschmidt 2016; Bittarello et al. 2017; Canudo 2018; Rosenberg and Clary 2018; Franza and Pratesi 2020). In this regard, the cataloguing of several naturalistic collections in Italy was promoted by the Italian University Museum Network, a project established and financed in 2012, involving 12 Italian universities (i.e. Bari, Cagliari, Chieti-Pescara, Ferrara, Firenze, Parma, Perugia, Roma "La Sapienza", Salento, Siena, and Tuscia), that aimed to the cataloguing of the most significant sections of the natural history collections belonging to these academic institutions through the ICCD standards. The results of catalogue campaigns were then included in the National Catalogue of Cultural Properties as well as they were used to organize preservation and valorisation activities to facilitate the study and the management of the university museum collections (Corradini 2012, 2016, 2019; Corradini and Campanella 2014).

Nevertheless, the Catalogue of National Cultural Properties shows how the geoscientific heritage, on the whole, still suffers from a lack of widespread cataloguing as there are few scientific museum institutions (i.e. the Natural History Museum of the University of Firenze and the Michelangelo Museum at Caserta) that have decided to carry out a cataloguing campaign using the two BN-M, BN-PE standards. And surprising, no meteorite collections (BN-PL standard) have been catalogued or included in the Catalogue of National Cultural Properties at the time of writing this work. Even if the topic is beyond the scope of this work, it has to be said that meteorite collections are preserved worldwide in scientific institutions (e.g. the Nation Institute of Polar Research in Tokyo or the NASA Johnson Space Centre in Houston) as well as in significant natural history museums as the Naturhistorisches Museum in Wien, the Museum für Naturkunde in Berlin, the National Museum of Natural History in London, the National Museum of Natural History in Paris, the Russian Academy of Science, the National Museum of Natural History in Washington, the American Museum of Natural History in New York, and the Western Australian Museum in Perth (Bevan 2013; Brandstätter 2013; Caillet Komorowski 2013; Clarke et al. 2013; Ebel 2013; Greshake 2013; Kojima 2013; Ivanova and Nazarov 2013; Russell and Grady 2013). Although not extensive as the those aforementioned, Italy has a number of important meteorite collections, which have been the core of a lively scientific debate throughout the years (Gallitelli 1974; Perchiazzi and Mellini 1995; Cipriani and Corazza 1998; Cipriani et al. 1999; Zuanetti 1999; Folco and Rastelli 2000, 2002; Folco et al. 2002; Folco and Zeoli 2005; Perchiazzi et al. 2004; Costa and Gallo 2009a,b; Maccagni 2011; Fioretti and Finotti 2012; Pratesi 2012a, b; Costa et al. 2018; Zucchini et al. 2018; Franza and Pratesi 2020; Franza et al. 2021). The meteorites that fell on the Italian peninsula over the centuries, which are now housed in museum naturalistic collections, represent a naturalistic heritage of great historical and scientific value. As an example, the meteorite that fell on Siena in 1794 was defined by Marvin $(1995,1998)$ as one of the history's most consequential fall, since the analysis of the recovered samples contributed to the acceptance of meteorites' cosmic origin. However Italian meteorite collections have not only a historical significance, but they are also an important source of extra-terrestrial material for research purposes. Cataloguing meteorite specimens in naturalistic collections along with their relative archival documents, museum catalogues and inventories can lead to a better characterization of previously analysed samples and to the potential discovery of meteorites unknown to the scientific community (Trevisani 2011; Moggi Cecchi et al. 2015, 2019a; Pratesi et al. 2019; Llorca et al. 2020; Marocchi et al. 2020). Furthermore, as rightly suggested by Dorfman (2012), meteorite collections hold many levels of intangible values (Ahmed 2006). For instance, Wilson (2020) pointed out how meteorite collections showed the naturalistic heritage as a mean of moral and social witnessing. This author argued that temporary or permanent exhibition focusing on astronomy and planetary sciences allow visitors to observe, through both the display of meteorite specimens and educational apparatus that described the discovery and the study of meteorite fragments, how humans have interacted with the cosmic environment underlining that "humanity is not the measure but a component in a wider system that is dependent upon the relationships that are built within it" (Burke 1991; Bignami 2004; White et al. 2010; Madiedo 2012; Setti 2012; Flamini 2014; Hutson et al. 2015; Day et al. 2017; Corrigan et al. 2018; Tiedeken et al. 2018; Moggi Cecchi et al. 2019b; Willis et al. 2019). Meteorites collections in natural history museums are, therefore, representative of scientific, historical, and cultural meanings that added extra value to a specimen. Consequently, a rigorous cataloguing through predeterminate criteria, as the BN-PL cataloguing standard realized by the ICCD, could lead to more precise conservation policies and management strategies of the astromaterials (e.g. McCubbin et al. 2019) preserved in Italian natural history museums. For instance, a standardized cataloguing of meteorite samples could provide a common basis for the exchange of information and help in resolving the problems related to the preservation of meteorite collections in case of sample transfer to research and teaching laboratories or scientific exhibition.

The cataloguing through standardised criteria also proved useful for the management of geoethical aspects relative to geoscientific heritage (Fig. 4). As stated by Peppoloni and Di Capua (2015), Bobrowsky et al. (2017) the term geoethics "consists of research and reflection on the values which underpin appropriate behaviours and practices, wherever human activities interact with the Earth system." An 


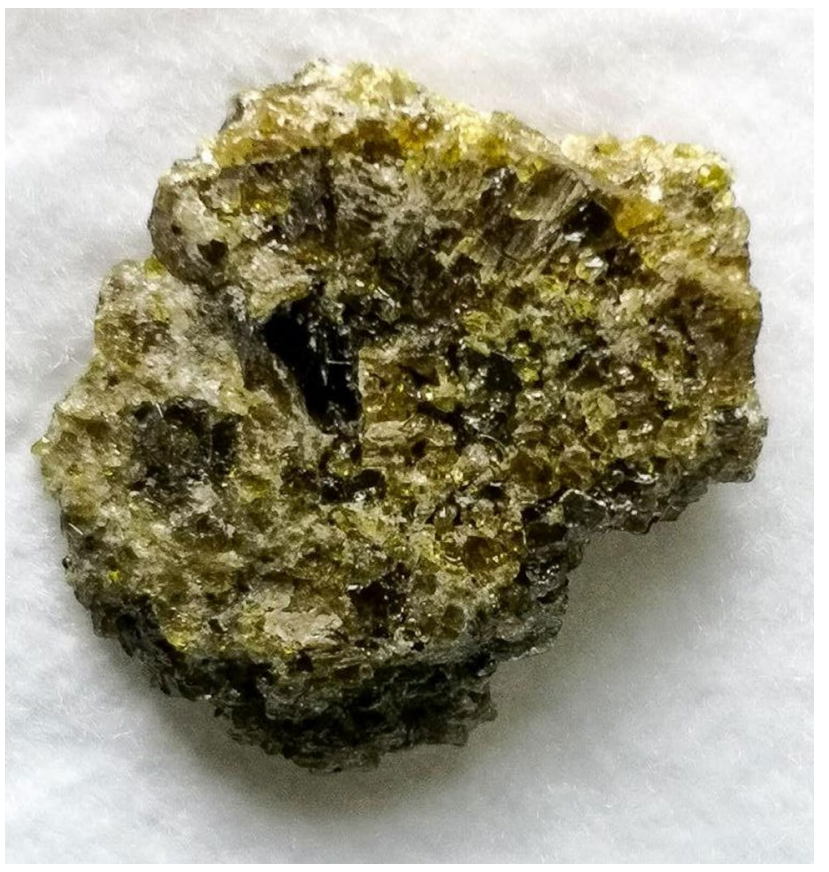

Fig. 4 NWA 6704 ungrouped achondrite (from the collections of the Museo di Scienze Planetarie in Prato). According to the rules of the Nomenclature Committee of the Meteoritical Society, each new meteorite specimen (unless it is a fragment from another sample or paired with other samples) represents a type specimen that has to be preserved with care and following professional procedures in official repositories. Therefore, a cataloguing of these specimens is obliged

interesting meaning of the word geoethics emerged during the 34th International Geological Congress held in Brisbane in 2012 where geoethics was defined as "an interdisciplinary field, which involves Earth and Planetary Sciences as well as applied ethics, regarding the study of abiotic world (geoeducation, natural hazards, geo-mining, engineering geology, communication, geoconservation, etc.). [...] In addition, the necessity of considering appropriate protocols, scientific integrity issues and a code of good practice is covered by this discipline. Planetary geology and astrobiology also require a geoethical approach" (Martínez-Frías 2013; Di Capua et al. 2017). Considering the latter definition, the cataloguing of geoscientific heritage through standardised criteria became more than a procedure to "keep update" the catalogues of the mineral, rock and meteorite collections preserved in Italian natural history museum. In fact, as shown in the previous section, the BN-M, BN-PE and BN-PL cataloguing standards contain not only geological and mineralogical data about the catalogued specimen but also social and cultural data of certain geoethical interest. For instance, the BN-PL cataloguing standard gives information useful to prevent bad scientific practices and ethical misconduct in planetary sciences (Baratoux et al. 2018; Persson et al. 2018; Vasconcelos et al. 2017; Martínez-Frías et al. 2010). In particular, a rigorous and objective cataloguing of meteorite specimens could help both museum curators and researchers to prevent the black market of meteorites, providing clear data about the place of recovery and the manner in which the meteorite specimen was acquired. This is a key information considering that international laws about meteorite acquisition are not uniform (Schmitt 2002; Fasan 2004; Gounelle and Gounelle 2019). In this regard, the ICOM Code of Ethics for Museums (2013) pointed out how museums have to supervise new acquisitions to ensure that any specimen for purchase, gift, loan, bequest, or exchange had not been illegally obtained. Furthermore, museums should not acquire specimens where there is reasonable cause to believe their recovery involved unauthorised or unscientific fieldwork or damage to geological sites. In the same way, acquisitions should not occur if there has been failure to disclose the finds to the owner of the land or to governmental authorities. To prevent illegal traffic in naturalistic, cultural and scientific objects, museums should establish the full history of the item since discovery to acquisition. To sum up, museums should not acquire geological specimens that have been collected, sold or otherwise transferred in contravention of local, national, regional or international law (ICOM Code of Ethics for Museums, art. 2.3-2.4 and 2.6). In this regard, the cataloguing standards realized by ICCD provide museum curators with exhaustive information about the place of recovery, the authors of the discovery, the modalities of acquisition as well as verified scientific data relative to the specimen (Pratesi et al. 2014; Moggi Cecchi et al. 2017).

The findings discussed in this section suggest that the cataloguing of geoscientific heritage using the ICCD standards (i.e. BN-M, BN-PE, BN-PL) provides paramount information useful for the conservation and the development of management strategies that have to be adapted to the type of catalogued specimen (i.e., mineral, rocks or meteorite specimens). As an example, these data are extremely useful in the conservation and valorisation of geoscientific heritage specimens using non-destructive techniques (e.g. Artioli 2013; Moggi Cecchi 2014; Balletti and Guerra 2015; Marinangeli et al. 2015; Taccetti et al. 2019; Cesareo et al. 2020; Colombo et al. 2020), because it allows to retrieve information about the history of a sample otherwise unknowable. This multidisciplinary approach, which focuses on cataloguing by combining the methodologies of historical analysis with instrumental techniques, improves the valorisation of historical collections as valuable primary sources in geo-mineralogical research (e.g. D'Amico and De Angelis 2009; Mottana et al. 2012; D'Amico et al. 2013; Borghi et al. 2015, 2020; Migaszewski and Mader 2019).

The ICCD cataloguing standards then provide useful data for the study and the evaluation of legislative, conservative, 
and management plans to promote effective research, didactic and educational strategies for an optimum valorisation of the Italian mineralogical, petrological and planetological heritage. Future work is required to establish the motivations (e.g., lack of training for compiling the cataloguing cards, shortage of qualified staff and financial resources etc.) of the low level of participation of scientific, museum and academic institutions to cataloguing their naturalistic collections using these standards. However, it worth mentioning that the Museo di Scienze Planetarie in Prato is going to launch a cataloguing campaign using the BN-PL standard by the end of 2020 whereas the meteorite collection of the Natural History Museum of the University of Firenze, that has been already catalogued using the same standard, will be included in the National Catalogue of Cultural Heritage as soon as the scientific validation of the cards will be performed.

\section{Conclusions}

ICOM Code of Ethics for Museums (2013) stated how museums have the responsibility for making collections and all relevant information pertaining to them available as freely as possible to the scholarly communities (art. 3.2). This aim could not be achieved without a proper cataloguing of museum heritage through objective, standardized and predeterminate criteria. The aim of the present study was to examine the three different cataloguing standards realised by the ICCD to catalogue mineralogical, petrological and planetological heritage preserved in Italian natural history museums and academic institutions. The investigation of the BN-M, BN-PE, and BN-PL cataloguing standards showed that these standards provide scholars and museum operators with in-depth information about the scientific, social and cultural history of the catalogued specimens. These standards - that it is worth reminding are the unique official national standards - may provide detailed information about rock, mineral, and meteorite specimens preserved in Italian public or private natural history museums according to well established and recognised criteria. The data are then organised and gathered through a single and official repository-the SIGECWeb online database. It is noteworthy to stress this point because the use of SIGECweb, which is the official repository of MiBAC, allows to trace and maintain over time the numerous cataloguing campaigns that are currently carried out in natural history museums and to save public financial resources. In fact, the greatest investment in cataloguing (alongside financial resources) is the human investment, with experts analysing and recording data that often end (and get lost) in a "grey area", owing to the adoption of diverse and local electronic cataloguing management systems. Carrying out a cataloguing campaign that does not use neither standardised criteria to collect the data nor official databases to make them available to the scholarly community means wasting financial and human resources in processing information that cannot be useful to know the actual composition of the Italian naturalistic, cultural and scientific heritage. Furthermore, cataloguing campaigns are often reported in non-indexed journals that are not included in any database or directory. This is another and not marginal aspect that contributes to the loss of the data collected. Although this study focused on illustrating the cataloguing of geoscientific heritage through the standards proposed by the ICCD, the findings might also have a bearing on the pivotal role that museums have in attract wider audiences for didactic and recreative purposes. In fact, the cataloguing of mineralogical, petrological and planetological heritage through the BN-M, BN-PE and BN-PL standardised models provided well-founded and accurate data that could be used in displays and temporary or permanent exhibitions. Museum collections indeed reflect the naturalistic, scientific and cultural heritage of the communities from which they have derived and a proper study through a standardised cataloguing could increase the public understanding of the contributions of geological museums to society as well as enhancing social resilience through the fruition of geoscientific heritage (Ghiara 2011; Carpino 2015; Carpino and Morelli 2016; Carpino et al. 2017, 2019; Petrosino et al. 2019).

Acknowledgements The authors would like to thank ICCD (MIBAC) and CRUI who have promoted the establishment of the national cataloguing standards for scientific, naturalistic and cultural heritage. We also acknowledge the Fondazione Cassa di Risparmio di Firenze for providing the financial support to successfully complete this article through the fund MECSO "Meteoroid Characterization through Spectroscopic Observation".

Funding Open Access funding provided by Università degli Studi di Firenze. This work was supported by the Fondazione Cassa di Risparmio di Firenze with the grant MECSO "Meteoroid Characterization through Spectroscopic Observation".

Data availability None.

Code availability None.

\section{Compliance with ethical standards}

Conflicts of interest The authors declared that they have no conflict of interest.

Open Access This article is licensed under a Creative Commons Attribution 4.0 International License, which permits use, sharing, adaptation, distribution and reproduction in any medium or format, as long as you give appropriate credit to the original author(s) and the source, provide a link to the Creative Commons licence, and indicate if changes were made. The images or other third party material in this article are included in the article's Creative Commons licence, unless indicated 
otherwise in a credit line to the material. If material is not included in the article's Creative Commons licence and your intended use is not permitted by statutory regulation or exceeds the permitted use, you will need to obtain permission directly from the copyright holder. To view a copy of this licence, visit http://creativecommons.org/licenses/by/4.0/.

\section{References}

Agnelli P, Barbagli F, Biddittu A, Brugnoli A, Calandra V, Castellani P, Ferrante F, Latella L, Mizzan L, Muscio G, Pesce GB, Scali S, Scandurra P (2007) Scheda BNZ. Beni Naturalistici-Zoologia, ICCD, Roma

Ahmed Y (2006) The scope and definitions of heritage: from tangible to intangible. Int J Herit Stud 12:292-300. https://doi. org/10.1080/13527250600604639

Al-Kathiri A, Hofmann BA, Jull AJT, Gnos E (2005) Weathering of meteorites from Oman: correlation of chemical/mineralogical weathering proxies with ${ }^{14} \mathrm{C}$ terrestrial ages and the influence of soil chemistry. Meteorit Planet Sci 40:1215-1239. https://doi. org/10.1111/j.1945-5100.2005.tb00185.x

Angelelli F, Barbagli F, Corradini E, Cioppi E, D'arpa C, Del Favero L, Ferrante F, Fornasiero M, Fresina A, Maganuco S, Mancinelli ML, (2008) Scheda BNP. Beni Naturalistici-Paleontologia, ICCD, Roma

Armiraglio S, Cuccuini P, Dal Lago A, Mancinelli ML, Martellos S, Pesce GB, Scandurra P (2007) Scheda BNB. Beni NaturalisticiBotanica, ICCD, Roma

Artioli G (2013) Science for the cultural heritage: the contribution of X-ray diffraction. Rend Fis Acc Lincei 24:55-62. https://doi. org/10.1007/s12210-012-0207-z

Bailey SW (1980) Summary of recommendations of AIPEA nomenclature committee on clay minerals. Am Mineral 65:1-7. https ://doi.org/10.1180/claymin.1980.015.1.07

Bailey SW (1982) Nomenclature for regular interstratifications. Am Mineral 67:394-398. https://doi.org/10.1180/claym in.1982.017.2.09

Balletti C, Guerra F (2015) The survey of cultural heritage: a long story. Rend Fis Acc Lincei 26:115-125. https://doi.org/10.1007/ s12210-015-0411-8

Barale I, Borghi A, Gallo LM, Giacobino E (2014) Carlo Boreani e la collezione di rocce dell'Egitto al Museo di Mineralogia e Petrografia dell’Università di Torino. Museol Scie 11:22-26

Baratoux D, Chennaoui-Aoudjehane H, Gibson R, Lamali A, Reimold WU, Selom Sepah M et al (2018) The Africa initiative for planetary and space sciences. American Geophysical Union, Fall Meeting 2017, abstract \#ED23B-0294

Barettino D, Winbledon WAP, Gallego E (2000) Geological heritage: its conservation and management. Instituto Geológico y Minero de España, Madrid

Bayliss P (2000) Glossary of obsolete mineral names. The mineralogical record, Tucson

Bayliss P, Levinson AA (1988) A system of nomenclature for rare-earth mineral species: revision and extension. Am Mineral 73:422-423

Beolchini F (2002) A relational database for the management of the collections housed in the G.B. Grassi Museum (University of Rome «La Sapienza»): a general survey. Rend Fis Acc Lincei 13:65-69. https://doi.org/10.1007/BF02904677

Bevan AWR (2013) The Western Australian Museum meteorite collection. In: McCall GJH, Bowden AJ, Howarth R.J (eds), The History of Meteoritics and Key Meteorite Collections: Fireballs, Falls and Finds, Geological Society of London, London 305-323

Bignami GF (2004) La vita e i pianeti: il mito e la scienza. Rend Fis Acc Lincei 15:267-279. https://doi.org/10.1007/BF02904466
Bittarello E, Marengo A, Gallo LM (2017) The "crystals collection" of the museum of mineralogy and petrography of the university of Turin. Museologia Scientifica 17:52-56

Bland PA, Smith TB, Jull AJT, Berry FJ, Bevan AWR, Cloudt S, Pillinger CT (1996) The flux of meteorites to the Earth over the last 50,000 years. Mon Not R Astron Soc 283:551-565. https://doi. org/10.1093/mnras/283.2.551

Bland PA, Sexton AS, Jull AJT, Bevan AWR, Berry FJ, Thornley DM, Astin TR, Britt DT, Pillinger CT (1998) Climate and rock weathering: a study of terrestrial age dated ordinary chondritic meteorites from hot desert regions. Geochim Cosmochim Acta 62:3169-3184. https://doi.org/10.1016/S0016-7037(98)00199-9

Bland PA, Cressey G, Menzies ON (2004) Modal mineralogy of carbonaceous chondrites by X-ray diffraction and Mössbauer spectroscopy. Meteorit Planet Sci 39:3-16. https://doi. org/10.1111/j.1945-5100.2004.tb00046.x

Bobrowsky P, Cronin V, Di Capua G, Kieffer S, Peppoloni S (2017) The emerging field of geoethics. In: Gundersen LC (ed) Scientific integrity and ethics: with applications to the geosciences. American Geophysical Union, New York, pp 175-212

Borgheresi M, Di Benedetto F, Caneschi A, Pratesi G, Romanelli M, Sorace L (2007) An EPR and SQUID magnetometry study of bornite. Phys Chem Miner 34:609-619. https://doi.org/10.1007/ s00269-007-0175-5

Borghi A, Angelici D, Borla M, Castelli D, D’Atri A, Gariani G, Lo Giudice A, Martire L, Re A, Vaggelli G (2015) The stones of the statuary of the Egyptian Museum of Torino (Italy): geologic and petrographic characterization. Rend Fis Acc Lincei 26:385-398. https://doi.org/10.1007/s12210-015-0441-2

Borghi A, Vignetta E, Ghignone S, Gallo M, Vaggelli G (2020) The "stella polare" expedition (1899-1900): study and enhancement of the rock collection. Geoheritage 12:33. https://doi. org/10.1007/s12371-020-00460-9

Brandstätter F (2013) History of the meteorite collection of the natural history museum of Vienna. In: McCall GJH, Bowden AJ, Howarth RJ (eds) The history of meteoritics and key meteorite collections: fireballs. Falls and Finds, geological society of London, London, pp 123-133

Broz ME, Cook RF, Whitney DL (2006) Microhardness, toughness, and modulus of Mohs scale minerals. Am Mineral 91:135-142. https://doi.org/10.2138/am.2006.1844

Burek CV, Prosser CD (2008) The history of Geoconservation. The Geological Society, London

Burke JG (1991) Cosmic debris: meteorites in history. University of California Press, Berkeley

Caillet Komorowski VL (2013) The meteorite collection of the National Museum of Natural History in Paris, France. In: McCall GJH, Bowden AJ, Howarth RJ (eds) The history of meteoritics and key meteorite collections: fireballs. Falls and finds, geological society of London, London, pp 163-204

Calosso B, Di Lorenzo A, Lattanzi M (2008) SIGEC: general information system for the cataloguing of the national cultural heritage. Museologia Scientifica 2:21-24

Cammelli M (2016) I tre tempi del Ministero dei beni culturali. Aedon 3

Canudo JI (2018) The collection of type fossils of the natural science museum of the university of Zaragoza (Spain). Geoheritage 10:385-392. https://doi.org/10.1007/s12371-017-0228-1

Carpino S (2015) Meteoritica: una sperimentazione integrata per una diversa modalità di promozione e diffusione della cultura scientifica. Museologia Scientifica 9:111-112

Carpino S, Morelli M (2016) Comunicazione e accessibilità al Museo di Scienze Planetarie di Prato. Museologia Scientifica 15:92-95

Carpino S, Lundstrom MB, Corsi L (2017) Museo per tutti: esperienze di condivisione. Museologia Scientifica 16:81-84 
Carpino S, Lundstrom MB, Calvani D (2019) Ricordi ed emozioni al Museo. Museologia Scientifica 19:130-132

Carusone A, Olivetta L (2006) ThIST. Thesaurus Italiano di Scienze della Terra, APAT, Roma

Castellani P, Miniati M, Vannozzi F (2006) Catalogare il patrimonio scientifico e tecnologico: la scheda PST. ICCD, Roma

Casto L, Celi M, Ferrante F, Francescangeli R, Pesce GB, Pezzotta F, Pizzo M, Pratesi G, Scandurra P, Zorzin R (2007a) Scheda BNM. Beni Naturalistici-Mineralogia, ICCD, Roma

Casto L, Celi M, Ferrante F, Francescangeli R, Pesce GB, Pezzotta F, Pizzo M, Pratesi G, Scandurra P, Zorzin R (2007b) Scheda BNPE. Beni Naturalistici-Petrologia, ICCD, Roma

Casto L, Celi M, Ferrante F, Francescangeli R, Pesce GB, Pezzotta F, Pizzo M, Pratesi G, Scandurra P, Zorzin R (2007c) Scheda BNPL. Beni Naturalistici-Planetologia, ICCD, Roma

Cesareo R, Bustamante A, Azeredo S, Lopes RT, Franco RJ, Fernandez A (2020) Analytical studies on pre-Columbian gold and silver from the North of Peru. Rend Fis Acc Lincei 31:473484. https://doi.org/10.1007/s12210-020-00891-0

Cignoni GA, Meloni E (2019) Structuring and sharing of knowledge, information technologies and economy of cataloguing. Museologia Scientifica 18:84-86

Cipriani C (2007) La collezione mineralogica targioni tozzetti: gemme e pietre dure. Atti Accad Naz Lin 18:67-87

Cipriani C (2011) Le collezioni mineralogiche del Museo di Storia Naturale dell'Università di Firenze: dalle origini a oggi. L.S, Olschki, Firenze

Cipriani C, Corazza M (1998) Le meteoriti del Museo di Mineralogia di Firenze: nota I. Museologia Scientifica 14:229-246

Cipriani C, Poggi L (1994) Le collezioni del Museo di Mineralogia di Firenze: la formazione della collezione elbana. Atti Memorie'Accademia Fiorentina Scienze Morali Colombaria 59:165-184

Cipriani C, Corazza M, Olmi F, Pratesi G (1999) Le meteoriti del Museo di Mineralogia di Firenze: nota II, le condriti ordinarie. Museologia Scientifica 15:183-194

Clarke RS, Plotkin H, Mccoy T (2013) Meteorites and the Smithsonian Institution. McCall GJH, Bowden AJ, Howarth RJ. Fireballs, Falls and Finds, Geological Society of London, London, The history of meteoritics and key meteorite collections, pp 238-265

Clayton RN, Onuma N, Mayeda TK (1976) A classification of meteorites based on oxygen isotopes. Earth Planet Sci Lett 30:1018. https://doi.org/10.1016/0012-821X(76)90003-0

Colombo F, Sario G, Gordillo S, Fabra M (2020) Tracking rock sources of 3800-year-old burial goods using X-ray diffraction, electron microprobe analyses and X-ray mapping: a case study from Córdoba, Argentina. Rend Fis Acc Lincei 31:495-503. https://doi.org/10.1007/s12210-020-00905-x

Connolly HC (2016) Chondrules: the canonical and noncanonical views. J Geophys Res Planets 121:1885-1899. https://doi. org/10.1002/2016JE005113

Corradini E (2012) The new communication technologies for sharing and participatory Italian university museums. Univ Museum Collect J 5:133-146

Corradini E (2013) Cataloguing and new computer technologies to make naturalistic heritage accessible. Museologia Scientifica 9:33-39

Corradini E (2016) La rete dei Musei Universitari: diffusione e contestualizzazione del patrimonio culturale degli atenei, orientamento al metodo e alla cultura scientifica. In: Magnani L, Stagno L (eds), Atti del Convegno, Valorizzare il patrimonio culturale delle Università, Genova 20-21 novembre 2014, $131-142$

Corradini E (2019) I nuovi percorsi educativi della Rete Italiana dei Musei Universitari. Museologia Scientifica 18:39-45
Corradini E, Campanella L (2014) A national project for the Italian university museums network. Univ Museum Collect J 7:20-29

Corrigan CM, Mccoy T, Hoskin CJ, Lunning N (2018) The U.S. national meteorite collection: bringing the solar system to the nation. American Geophysical Union, Fall Meeting 2018, abstract \#ED23E-0950

Costa E, Gallo LM (2009a) The meteorite collection in the natural science museum of Turin. Publ Astron Soc Aust 26:259-265. https ://doi.org/10.1071/AS08035

Costa E, Gallo LM (2009b) Una caduta meteoritica nel comune di Montemagno (Asti). Bollettino del Museo Regionale di Scienze Naturali di Torino 25:435-444

Costa E, Marengo A, Bittarello E (2018) Le meteoriti del Museo di Mineralogia e Petrografia dell'Università e del Museo Regionale di Scienze Naturali di Torino. Regione Piemonte, Torino

Criddle AJ, Stanley CJ (1993) Quantitative data file for ore minerals. Springer, Berlin

D'Amico C, De Angelis MC (2009) Neolithic greenstone in umbria, from the bellucci collection. Petrography, provenance, interpretation. Rend Fis Acc Lincei 20:61-76. https://doi.org/10.1007/ s12210-009-0004-5

D’Amico C, Nenzioni G, Fabris S, Ronchi S, Lenzi F (2013) Neolithic tools in S. Lazzaro di Savena (Bologna): a petro-archaeometric study. Rend Fis Acc Lincei 24:23-38. https://doi. org/10.1007/s12210-012-0208-y

Day BH, Bland P, Sayers R (2017) Fireballs in the sky: an augmented reality citizen science program. American Geophysical Union, Fall Meeting 2017, abstract \#ED24B-01

De Fourestier J (1999) Glossary of mineral synonyms. The mineralogical association of Canada, Ottawa

De Fourestier J (2002) The naming of mineral species approved by the Commission of New Minerals and Mineral Names of the International Mineralogical Association: a brief history. Can Mineral 40:1721-1735

De Lima JTM, De Souza CI (2020) Geological or cultural heritage? The ex situ scientific collections as a remnant of nature and culture. Geoheritage 12:3. https://doi.org/10.1007/s1237 1-020-00448-5

Di Lorenzo P (2011) Il Museo “Michelangelo." In: Di Lorenzo P, Rea A (eds) Scientia Magistra Vitae, catalogo dei Musei, degli approfondimenti e delle mostre. Melagrana Onlus, San Felice a Cancello, pp 34-52

Di Capua G, Peppoloni S, Brobrowsky PT (2017) The cape town statement on geoethics. Ann Geophys-Italy 60:7. https://doi. org/10.4401/ag-7553

Dorfman E (2012) Intangible natural heritage: new perspectives on natural objects. Routledge, New York

Dunn PJ, Mandarino JA (1987) Formal definitions of type mineral specimens. Can Mineral 25:571-572. https://doi.org/10.1180/ minmag.1988.052.364.14

Ebel DS (2013) History of the American museum of natural history meteorite collection. In: McCall GJH, Bowden AJ, Howarth RJ (eds) The history of meteoritics and key meteorite collections: fireballs. Falls and Finds, Geological Society of London, London, pp 267-289

Farley SS, Dawson A, Goring SJ, Williams JW (2018) Situating ecology as a big-data science: current advances, challenges, and solutions. Bioscience 68(8):563-576. https://doi.org/10.1093/ biosci/biy068

Fasan E (2004) Planetary protection. Some legal questions Adv Space Res 34:2344-2353. https://doi.org/10.1016/j. asr.2004.01.017

Ferraris G, Gula A, Ivaldi G, Nespolo M, Sokolova E, Uvarova Y, Khomyakov AP (2001) First structure determination of an MDO-2O mica polytype associated with a $1 \mathrm{M}$ polytype11Dedicated to Professor Boris B. Zvyagin, in occasion of his 80th 
birthday, for his pioneering contributions to the polytypism of layer silicates. Eur J Mineral 13:1013-1023. https://doi. org/10.1127/0935-1221/2001/0013-1013

Fettes D, Desmons J (2011) Metamorphic rocks: a classification and glossary of terms recommendations of the International union of geological sciences subcommission on the systematics of metamorphic rocks. Cambridge University Press, Cambridge

Fioretti AM, Finotti F (2012) Le meteoriti del museo civico di rovereto. Annali Museo Civico di Rovereto 27:73-85

Flamini E (2014) The earth: one of the planets of the solar system. Rend Fi Acc Lincei 25:13-20. https://doi.org/10.1007/s1221 0-013-0275-8

Folco L, Rastelli N (2000) The meteorite collection of the Museo Nazionale dell'Antartide in Siena. Meteorit Planet Sci 35(S5):A189-A198. https://doi.org/10.1111/j.1945-5100.2000. tb01795.x

Folco L, Zeoli A (2005) The meteorite collection of the Italian Museo Nazionale dell'Antartide "Felice Ippolito" (December 2005 update). Terra Antartica 12(1):35-39

Folco L, Peri F, Pezzotta F (2002) The meteorite collection of the Civico Planetario and the Museo Civico di Storia Naturale in Milan, Italy. Meteorit Planet Sci 37:B95-B103. https://doi. org/10.1111/j.1945-5100.2002.tb00908.x

Franza A, Pratesi G (2020) Meteorites as a scientific heritage. Cons Patr https://doi.org/10.14568/cp2020018

Franza A, Petti C, Pratesi G (2021) More than just a rock collection. The meteorite collection of the Italian geologist Teodoro Monticelli. Earth Sci Hist 40(1):1-29

Gaines RV, Skinner HCV, Foord EE, Mason B, Rosenzweig A (1997) Dana's new mineralogy: the system of mineralogy of James Dwight Dana and Edward Salisbury Dana. New York, J. Wiley and Sons

Gallitelli P (1974) Le meteoriti del Museo dell'Istituto di Mineralogia e Petrografia dell'Università di Bologna. Atti Accademia Scienze Istituto Bologna Classe Scienze Fisiche Memorie 262(4):1-45

Garofano M (2015) Geowatching, a term for the popularisation of geological heritage. Geoheritage 7:25-32. https://doi.org/10.1007/ s12371-014-0114-z

Ghiara MR (2011) I Musei Scientifici della "Federico II": scienza e impegno sociale. Museologia Scientifica 7:38-46

Gippoliti S, Amori G, Castiglia R, Colangelo P, Capanna E (2014) The relevance of Italian museum collections for research and conservation: the case of mammals. Rend Fis Acc Lincei 25:351-357. https://doi.org/10.1007/s12210-014-0304-2

Giuli G, Pratesi G, Corazza M, Cipriani C (2000) Aluminium coordination in tektites: A XANES study. Am Mineral 85:1172-1174. https://doi.org/10.2138/am-2000-8-908

Giuli G, Eeckhout SG, Koeberl C, Pratesi G, Paris E (2008) Yellow impact glass from the K/T boundary at Beloc (Haiti): XANES determination of the Fe oxidation state and implications for formation conditions. Meteorit Planet Sci 43:981-986. https://doi. org/10.1111/j.1945-5100.2008.tb01093.x

Gounelle M, Gounelle M (2019) Meteorites: international law and regulations. Meteorit Planet Sci 54:2887-2901. https://doi. org/10.1111/maps.13396

Guida Italiana alla Classificazione e alla Terminologia Stratigrafica (2003), APAT 9

Grady M (2002) The catalogue of meteorites. Cambridge University Press, Cambridge

Grady M, Pratesi G, Moggi Cecchi V (2014) Atlas of meteorites. Cambridge University Press, Cambridge

Greshake A (2013) History of the meteorite collection at the Museum für Naturkunde, Berlin. In: McCall GJH, Bowden AJ, Howarth RJ (eds) The history of meteoritics and key meteorite collections: fireballs. Falls and Finds, Geological Society of London, London, pp 135-151
Hanner R, Corthals A, DeSalle R (2009) Biodiversity, conservation, and genetic resources in modern museum and herbarium collections. Amato G. Ryder OA, Rosenbaum HC, Conservation genetics in the age of genomics, Colombia University Press, New York, DeSalle R, pp 115-123

Hawthorne FC, Ungaretti L, Oberti R (1995) Site populations in minerals. Terminology and presentation of results of crystal-structure refinement. Can Mineral 33:907-911

Hermann K (2011) Hardness testing. Principles and Applications, ASM International, Ohio

Hewins RH (1997) Chondrules. Annu Rev Earth Pl 25:61-83. https:// doi.org/10.1146/annurev.earth.25.1.61

Hezel DC, Bland PA, Palme H, Jacquet E, Bigolski J (2018) Composition of chondrules and matrix and their complementary relationship in chondrites. In: Russel S, Connolly HC, Krot AN (eds) Chondrules. Cambridge University Press, Cambridge, Records of Protoplanetary Disk Processes, pp 91-121

Hoffman BT (2009) Art and cultural heritage. Cambridge University Press, Cambridge, Law, Policy and Practice

Hutson ML, Pugh RN, Ruzicka AM (2015) Lessons learned from meteorite public outreach and education in the Pacific Northwest. 46th lunar and planetary science conference, held march 16-20, 2015 in The Woodlands, Texas. LPI Contribution No 1832:1690

ICOM Code of Ethics for Museums (2013) International council of museums

Ivanova MA, Nazarov MA (2013) History of the meteorite collection of the Russian academy of science. McCall GJH, Bowden AJ, Howarth RJ. Fireballs, Falls and Finds, Geological Society of London, London, The History of Meteoritics and Key Meteorite Collections, pp 220-236

Ixer RA (1990) Atlas of opaque and ore minerals in their associations. J. Wiley \& Sons, New York

Jardine N (2013) Reflections on the preservation of recent scientific heritage in dispersed university collections. Stud Hist Philos Sci 44:735-743. https://doi.org/10.1016/j.shpsa.2013.07.009

Jull AJT, Wlotzka F, Palme H, Donahue DJ (1990) Distribution of terrestrial age and petrologic type of meteorites from western Libya. Geochim Cosmochim Acta 54:2895-2899. https://doi. org/10.1016/0016-7037(90)90028-J

Jull AJT, Wlotzka F, Donahue DJ (1991) Terrestrial ages and petrologic description of Roosevelt County meteorites. Lunar Planet Sci 24:667-668

Kays R, McShea WJ, Wikelski M (2020) Born-digital biodiversity data: millions and billions. Divers Distrib 26(5):644-648. https ://doi.org/10.1111/ddi.12993

Kimura M, Chen M, Yoshida Y, El Goresy A, Ohtani E (2003) Back transformation of high pressure phases in a shock melt vein of an $\mathrm{H}$-chondrite during atmosphere passage: implications for the survival of high-pressure phases after decompression. Earth Planet Sci Lett 217:141-150. https://doi.org/10.1016/S0012 $-821 \mathrm{X}(03) 00585-5$

Kojima H (2013) The history of Japanese Antarctic meteorites. In: McCall GJH, Bowden AJ, Howarth RJ (eds) The history of meteoritics and key meteorite collections: fireballs. Falls and Finds, Geological Society of London, London, pp 291-303

Komatsu G, Coletta A, Battagliere ML, Vivarelli M (2019) Sikjote Alin, Russia. In: Flamini E, Di Martino M, Coletta A (eds) Encyclopedic atlas of terrestrial impact craters. Springer, Berna, p 199

La Maitre RW, Streckeisen A, Zanettin B, Le Bas MJ, Bonin B, Bateman P (2002) Igneous rocks: a classification and glossary of terms: recommendations of the international union of geological sciences subcommission on the systematics of igneous rocks. Cambridge University Press, Cambridge

Leo J (2011) Museum collections in ornithology: today's record of avian biodiversity for tomorrow's world. Emu Austral Ornithol 111:1-13. https://doi.org/10.1071/MUv111n3_ED 
Levinson AA (1966) A system of nomenclature for rare-earth minerals. Am Mineral 51:152-158

Llorca J, Campeny M, Ibáñez N, Allepuz D, Camarasa JM, AurellGarrido J (2020) The meteorite of Barcelona (1704): history, discovery and classification. Meteorit Planet Sci 55(4):705-725. https://doi.org/10.1111/maps.13455

Loubar S (2017) Inside the Lost Museum. Harvard University Press, Cambridge

Lourenço MC, Wilson L (2013) Scientific heritage: reflections on its nature and new approaches to preservation, study and access. Stud Hist Philos Sci 44:744-753. https://doi.org/10.1016/j.shpsa .2013.07.011

Ludwig D, Weber C (2013) A rediscovery of scientific collections as material heritage? The case of university collections in Germany. Stud Hist Philos Sci 44:652-659. https://doi.org/10.1016/j.shpsa .2013.07.012

Maccagni B (2011) Museo del Cielo e della Terra. Li.pe, San Giovanni in Persiceto, pp 13-49

Madiedo JM (2012) Promoting the public's interest in meteor science and meteoritics in the framework of the windows to science project. European planetary science congress 2012, held 23-28 Sept 2012 in Madrid, Spain, id. EPSC2012-5

Magagna A, Ferrero E, Giardino M, Lozar F, Perotti L (2013) A selection of geological tours for promoting the italian geological heritage in the secondary schools. Geoheritage 5:265-273. https://doi. org/10.1007/s12371-013-0087-3

Makovicky E (1989) Classification modulaire des sulfosels. Neues Jb Miner Abh 160:269-297

Mancinelli ML (2018) Gli standard catalografici dell'Istituto Centrale per il Catalogo e la Documentazione. In: Tucci R (ed) Le voci, le opera e le cose. La catalogazione dei beni culturali demoentoantropologici, Roma, ICCD, pp 279-302

Mandarino AJ (1981) The Gladstone-Dale relationship. Part IV: the compatibility concept and its application. Can Mineral 19:441-450

Mandarino AJ (2007) The Gladstone-Dale compatibility of minerals and its use in selecting mineral species for further study. Can Mineral 45:1307-1324. https://doi.org/10.2113/gscan $\min .45 .5 .1307$

Manetti G, Valeri M (2012) La valutazione del patrimonio museale: il caso del Museo di Storia Naturale di Firenze. Financial Reporting 3:111-133

Marangoni C, Miglietta AM (2015) Progetto CollMap: valutazione e prospettive dei corsi di formazione per tassonomi. Museologia Scientifica 9:91-99

Marangoni C, Miglietta AM, Vomero V (2017) Corsi CollMap: valutazione delle richieste formative sulla tassonomia in ambito museale. Museologia Scientifica 16:163-166

Marengo A, Borghi A, Costa E (2014) La collezione "Marmi onice e alabastri” del Museo di Mineralogia e Petrografia dell'Università di Torino. Museologia Scientifica 8:39-46

Marinangeli L, Pompilio L, Baliva A, Billotta S, Bonanno G, Domeneghetti MC, Fioretti AM, Menozzi O, Nestola F, Piluso E, Pondrelli M, La Salvia V, Somma MC, Tateo F, Petrinca P, Di Giulio C, Tangari AC (2015) Development of an ultra-miniaturised $\mathrm{XRD} / \mathrm{XRF}$ instrument for the in situ mineralogical and chemical analysis of planetary soils and rocks: implication for archaeometry. Rend Fis Acc Lincei 26:529-537. https://doi.org/10.1007/ s12210-015-0477-3

Marocchi Y, Bonal L, Gattacceca J, Piani L, Beck P, Greenwood R, Eschrig J, Basque A, Nuccio PM, Foresta FM (2020) The Piancaldoli meteorite: A forgotten primitive LL3.10 ordinary chondrite. Meteorit Planet Sci 55:1-12. https://doi.org/10.1111/ maps.13552
Martin RF (1998) The nomenclature of minerals: a compilation of IMA reports. Mineral Assoc Canada

Martínez-Frías J (2013) Meteorites and impacts: research, cataloguing and geoethics. Seminarios SEM 10:75-87

Martínez-Frías J, Horneck G, De La Torre Noetzel T, Rull F (2010) A geoethical approach to the geological and astrobiological exploration and research of the Moon and Mars. 38th COSPAR Scientific Assembly. Held 18-15 July 2010, in Bremen, Germany, 5

Marvin UB (1993) The meteoritical society: 1933 to 1993. Meteorit Planet Sci 28:261-314. https://doi. org/10.1111/j.1945-5100.1993.tb00268.x

Marvin UB (1995) Siena, 1794: history's most consequential meteorite fall. Meteoritics 30(5):540541

Marvin UB (1998) The shower of stones at Siena, 1794: History's most consequential meteorite fall. In: Morello N (ed) INHIGEO. Volcanoes and History, Genova, Brigati, pp 303-321

Mazzi F, Bernardini GP (1992) Fondamenti di cristallografia e ottica cristallografica. Utet, Roma

McCubbin FM, Herd CDK, Yada T, Hutzler A, Calaway MJ, Allton $\mathrm{JH}$, Corrigan CM, Fries MD, Harrington AD, McCoy TJ, Mitchell JL, Regberg AB, Righter K, Snead CJ, Tait KT, Zolensky ME, Zeigler RA (2019) Advanced curation of astromaterials for planetary science. Space Sci Rev 215:48. https://doi.org/10.1007/ s11214-019-0615-9

Migaszewski ZM, Mader A (2019) The use of museum collection for studying the origin of "rose-like" calcite in the holy cross mountains (South-Central Poland). Geoheritage 11:1307-1314. https ://doi.org/10.1007/s12371-019-00369-y

Miniati M (2008) Cataloguing scientific instruments: from SIC to PST. Museol Scie 2:18-20

Moggi Cecchi V (2014) L'applicazione della spettroscopia Raman allo studio delle meteoriti e dei minerali delle collezioni del Museo di Scienze Planetarie della Provincia di Prato. Museol Scie 11:157-160

Moggi Cecchi V, Carpino S, Pratesi G, Caporali S, Manetti F (2015) Tale of a rediscovered meteorite: the case of the meteorite Slaghek's Iron. Museologia Scientifica 14:166-168

Moggi Cecchi V, Pratesi G, Carpino S, Caporali S (2017) The meteorite classification on behalf of a third party as an efficient tool for the economic valorisation and the scientific promotion of the heritage of the naturalistic collections. Museol Sci 17:144-147

Moggi Cecchi V, Rossi M, Ghiara MR, Pratesi G, Franza A (2019a) An unrevealed treasure: a new Italian meteorite from the royal mineralogical museum of Naples. Geol Today 35:212-216. https ://doi.org/10.1111/gto.12293

Moggi Cecchi V, Pratesi G, Franza A (2019b) See to believe. Meteorite collections at the forefront of science communication in society. EPSC-DPS joint meeting 2019, held 15-20 Sept 2019 in Geneva, Switzerland, id. EPSC-DPS2019-585

Moro L (2015) Il catalogo del patrimonio culturale italiano. Nuove centralità e prospettive future. Economia della Cultura 25:419-432

Moro L (2017) Quale governance per il Catalogo nazionale dei beni culturali. Aedon 1

Mottana A, Mussino A, Nasti V (2012) Minerals from the carpathian mountains and from transylvania donated by joseph II (1785) to the Museum of the Collegio Nazareno, Rome, Italy. Central Eur Geol 55:103-122. https://doi.org/10.1556/CEuGeol.55.2012.1.6

Nesse WD (2004) Introduction to optical mineralogy. Oxford University Press, Oxford

Paradiso D, Francescangeli R, Corriero G (2015) The BN-Z standard for the zoological cultural heritage: an experience in the Biological Department Museum "Lidia Liaci." Museol Scie 14:11-17

Peppoloni S, Di Capua G (2015) The meaning of Geoethics. In: Wyss M, Peppoloni S (eds) Geoethics: ethical challenges and case studies in earth sciences. Elsevier, Amsterdam, pp 3-14 
Perchiazzi N, Mellini M (1995) Revisione e riclassificazione della collezione di meteoriti del Museo di Storia Naturale dell'Università di Pisa. Atti Soc Toscana Sci Nat Mem Serie A 102:1-4

Perchiazzi N, D’Orazio M, Folco L (2004) The meteorite collection at the Museo di Storia Naturale, Pisa University, Italy. Meteorit Planet Sci 39:A171-A176. https://doi. org/10.1111/j.1945-5100.2004.tb00354.X

Persson E, Martínez Frías J, Milligan T, Arnould J, Kminek G (2018) The international context of astrobiology. In: Capova K, Persson E, Milligan T, Dunér D (eds) Astrobiology and society in Europe today. Springer Briefs in Astronomy. Springer, Cham, pp 11-17

Petrosino P, Iavarone R, Alberico I (2019) Enhancing social resilience through fruition of geological heritage in the vesuvio national park. Geoheritage 11:2005-2024. https://doi.org/10.1007/s1237 1-019-00404-y

Petti C, Toscano M, Ghiara MR (2015) Dall'esposizione al racconto: evoluzione del ruolo delle collezioni del Real Museo Mineralogico. Museologia Scientifica 14:125-131

Plances E, Benes E (2015) Sull'uso della tecnologia RFId nei processi di gestione dei beni culturali. Ann Univ Ferrara Museol Scie Nat 11:61-68

Pratesi G (2012) Per aspera ad astra. La collezione di meteoriti. In: Pratesi G (ed) Museo di Storia Naturale dell'Università degli Studi di Firenze. Le collezioni mineralogiche e litologiche, Firenze University Press, Firenze, pp 127-142

Pratesi G (2012) Museo di storia naturale dell'università degli studi di firenze. Firenze University Press, Firenze, Le collezioni mineralogiche e litologiche

Pratesi G, Bartolozzi L, Cioppi E, Di Fazio L, Nepi C, Poggi L, Zavattaro M (2014) Individuazione dei criteri per la stima del valore dei beni naturalistici e demoetnoantropologici. In: Pratesi G, Vannozzi F (eds) I valori del museo. Politiche di indirizzo e strategie di gestione, FrancoAngeli, Milano, pp 81-97

Pratesi G, Caporali S, Greenwood RC, Moggi Cecchi V, Franchi IA (2019) A detailed mineralogica, petrographic, and geochemical study of the highly reduced chondrite, Acfer 370. Meteorit Planet Sci 54:2996-3017. https://doi.org/10.1111/maps.13409

Pruseth KL (2009) Calculation of the CIPW norm: new formulas. J Earth Syst Sci 118:101. https://doi.org/10.1007/s1204 0-009-0010-0

Re A, Angelici D, Lo Giudice A, Maupas E, Giuntini L, Calusi S, Gelli N, Massi M, Borghi A, Gallo LM, Pratesi G, Mandò PA (2013) New markers to identify the provenance of lapis lazuli: trace elements in pyrite by means of micro-PIXE. Appl Phys A 111:69-74. https://doi.org/10.1007/s00339-013-7597-3

Re A, Angelici D, Lo Giudice A, Corsi J, Allegretti S, Biondi AF, Gariani G, Calusi S, Gelli N, Giuntini L, Massi M, Taccetti F, La Torre L, Rigato V, Pratesi G (2015) Ion beam analysis for the provenance attribution of lapis lazuli used in glyptic art: the case of the "collezione medicea. Nucl Instrum Methods Phys Res B 348:278-284. https://doi.org/10.1016/j.nimb.2014.11.060

Reis J, Póvoas L, Barriga FJAS, Lopes C, Santos VF, Ribeiro B, Cascalho J, Pinto A (2014) Science education in a museum: enhancing earth sciences literacy as a way to enhance public awareness of geological heritage. Geoheritage 6:217-223. https://doi. org/10.13140/2.1.3726.9127

Rosenberg G, Clary RM (2018) Museums at the forefront of the history and philosophy of geology: history made, history in the making. Geological society of America, Boulder

Rubin A (1997) Mineralogy of meteorite groups: an update. Meteorit Planet Sci 32:733-734. https://doi. org/10.1111/j.1945-5100.1997.tb01558.x

Rubin A (2004) Postshock annealing and postannealing shock in equilibrated ordinary chondrites: implications for the thermal and shock stories of chondritic asteroids. Geochim Cosmochim Acta 68:673-689. https://doi.org/10.1016/S0016-7037(03)00452-6

Russell S (2018) Possible Chondrule-Forming Mechanisms. In: Russell S (ed) Chondrules. Cambridge University Press, Cambridge, Records of Protoplanetary Disk Processes, pp 341-436

Russell S, Grady M (2013) A history of the meteorite collection at the Natural History Museum, London. McCall GJH, Bowden AJ, Howarth RJ. Fireballs, Falls and Finds, Geological Society of London, London, The History of Meteoritics and Key Meteorite Collections, pp 155-162

Sanero E, Gottardi G (1968) Nomenclature and crystal-chemistry of axinites. Am Mineral 53:1407-1410

Schmitt DG (2002) The law of ownership and control of meteorites. Meteorit Planet Sci 37:B5-B11. https://doi. org/10.1111/j.1945-5100.2002.tb00897.x

Schmitt RT, Stöffer D (1995) Experimental data in support of the 1991 shock classification of chondrites. Meteoritics 30:574-575

Schmitt RT, Deutsch A, Stöffer D (1994) Shock experiments with the H6 chondrite Kernouvé: pressure calibration of microscopic shock effects. Meteorit Planet Sci 29:529-530. https://doi. org/10.1111/j.1945-5100.2000.tb01435.x

Setti G (2012) Astronomy and society. Rend Fis Acc Lincei 23:39-46. https://doi.org/10.1007/s12210-012-0198-9

Stoffler D, Keil K, Scott ERD (1991) Shock metamorphism of ordinary chondrites. Geochim Cosmochim Acta 55:3845-3867

Strunz H, Nickel E (2001) Strunz mineralogical tables: chemical structural mineral classification system. Schweizerbart, Stuttgart

Suarez AV, Tsutsui ND (2004) The value of museum collections for research and society. Bioscience 54:66-74. https://doi. org/10.1641/0006-3568(2004)054[0066:TVOMCF]2.0.CO;2

Taccetti F, Castelli L, Czelusniak C, Gelli N, Mazzinghi A, Palla L, Ruberto C, Censori C, Lo Giudice A, Re A, Zafiropulos D, Arneodo F, Conicella V, Di Giovanni A, Torres R, Castella F, Mastrangelo N, Gallegos D, Tascon M, Marte F, Giuntini L (2019) A multipurpose X-ray fluorescence scanner developed for in situ analysis. Rend Fis Acc Lincei 30:307-322. https://doi. org/10.1007/s12210-018-0756-X

Tiedeken S, Jones AP, Wasser ML, Whelley N (2018) Engaging the public with planetary science using hands-on activities. American Geophysical Union, Fall Meeting 2018, abstract \#PA23E-1028

Trevisani E (2011) History of the Vigarano meteorite (EmiliaRomagna, Italy) and recovery of an important part of the main mass. Rend Fis Acc Lincei 22:315-326. https://doi.org/10.1007/ s12210-011-0137-1

Vasconcelos L, Martínez Frías J, Mogessie A (2017) Geoethics Africa needs to be respected and heard. J Afr Earth Sci 111:287. https ://doi.org/10.1016/j.jafrearsci.2015.08.008

Vicentini CB, Buldrini F, Bosi G, Romagnoli C (2018) "Spigo nardo": from the erbario estense a possible solution for its taxonomical attribution. Rend Fis Acc Lincei 29:909-921. https://doi. org/10.1007/s12210-018-0739-y

Vicentini CB, Buldrini F, Romagnoli C, Bosi G (2020) Tobacco in the erbario estense and other renaissance evidence of the columbian taxon in Italy. Rend Fis Acc Lincei. https://doi.org/10.1007/ s12210-020-00959-x

Volpe G (2016) Un patrimonio italiano: Beni culturali, paesaggio e cittadini. Utet, Roma

Vomero V (2013) Biodiversità, banche dati tassonomiche e Musei scientifici. Il progetto nazionale CollMap come premessa per il lancio di un istituto diffuso italiano di tassonomia. Museologia Scientifica 9:21-27

Walisch T, Pepin C, Braun P (2019) How the Luxembourg natural history museum has established and maintained a national 
bio- and geodiversity data system. Biodiver Inform Sci Standards 3:e37470. https://doi.org/10.3897/biss.3.37470

Weisberg MK, Mccoy TJ, Krot AN (2006) Systematics and Evaluation of Meteorite Classification. In: Lauretta Dante S, McSween HY (eds) Meteorites and the Early Solar System II. University of Arizona Press, Tucson, pp 19-52

White V, Gurton S, Berendsen M, Dusenbery P (2010) Making an impact with public outreach activities on asteroids, comets, and meteorites. American Geophysical Union, Fall Meeting 2010, abstract id. ED51A-0506

Willis KJ, Graff PV, Runco S, Foxworth S (2019) Connecting with the public: explaining the significance of scientific work using unique assets and personal communication. American Geophysical Union, Fall Meeting 2019, abstract \#ED11D-0885

Wilson RJ (2020) Natural history: heritage. Place and Politics, New York, Routledge

Wlotzka F (1993) A weathering scale for the ordinary chondrites. Meteoritics 28:460

Wlotzka F, Jull AJT, Donahue DJ (1995) Carbon-14 terrestrial ages of meteorites from Acfer. Algeria LPI Tech Rpt 95-02:72-73
Wolfschmidt G (2016) Enhancing university heritage-based research. Tredition, Hamburg

Yaroshevsky AA, Ivanov AV (2010) Geochemical diversity of meteorite minerals: systematics and nomenclature of phosphides and silicides. Geochem Int 48:808. https://doi.org/10.1134/S0016 702910080070

Zuanetti A (1999) La collezione dei meteoriti del Museo di Mineralogia dell'Università di Padova. Studio classificativo e valorizzazione didattica. Dissertation, University of Padua, Padua, Italy

Zucchini A, Petrelli M, Frondini F, Petrone CM, Sassi P, Di Michele A, Palmerini S, Trippella O, Busso M (2018) Chemical and mineralogical characterization of the Mineo (Sicily, Italy) pallasite: a unique sample. Meteorit Planet Sci 53(2):268-283. https://doi. org/10.1111/maps.13002

Publisher's Note Springer Nature remains neutral with regard to jurisdictional claims in published maps and institutional affiliations. 